\title{
Verkenning van de invloed van reisafstand op de keuze voor een middelbare beroepsopleiding
}

Citation for published version (APA):

Bertrand-Cloodt, D. A. M., Cörvers, F., Heijke, J. A. M., \& van Thor, J. A. F. (2011). Verkenning van de invloed van reisafstand op de keuze voor een middelbare beroepsopleiding. ROA. ROA Technical Reports No. 001 https://doi.org/10.26481/umarot.2011001

Document status and date:

Published: 01/01/2011

DOI:

10.26481/umarot.2011001

Document Version:

Publisher's PDF, also known as Version of record

\section{Please check the document version of this publication:}

- A submitted manuscript is the version of the article upon submission and before peer-review. There can be important differences between the submitted version and the official published version of record.

People interested in the research are advised to contact the author for the final version of the publication, or visit the DOI to the publisher's website.

- The final author version and the galley proof are versions of the publication after peer review.

- The final published version features the final layout of the paper including the volume, issue and page numbers.

Link to publication

\footnotetext{
General rights rights.

- You may freely distribute the URL identifying the publication in the public portal. please follow below link for the End User Agreement:

www.umlib.nl/taverne-license

Take down policy

If you believe that this document breaches copyright please contact us at:

repository@maastrichtuniversity.nl

providing details and we will investigate your claim.
}

Copyright and moral rights for the publications made accessible in the public portal are retained by the authors and/or other copyright owners and it is a condition of accessing publications that users recognise and abide by the legal requirements associated with these

- Users may download and print one copy of any publication from the public portal for the purpose of private study or research.

- You may not further distribute the material or use it for any profit-making activity or commercial gain

If the publication is distributed under the terms of Article $25 \mathrm{fa}$ of the Dutch Copyright Act, indicated by the "Taverne" license above, 
Maastricht University

Research Centre for Education and the Labour Market | ROA

\section{Verkenning van de invloed van reisafstand op de keuze voor een middelbare beroepsopleiding}

D. Bertrand-Cloodt

F. Cörvers

H. Heijke

J. van Thor

\section{ROA Technical Report}

ROA-TR-2011/1

Research Centre for Education and the Labour Market Maastricht University

P.O. Box 616,6200 MD Maastricht, The Netherlands

$\mathrm{T}+31433883647 \mathrm{~F}+31433884914$

secretary-roa-sbe@maastrichtuniversity.n www.roa.nl 


\section{Verkenning van de invloed van reisafstand op de keuze voor een middelbare beroepsopleiding}

D. Bertrand-Cloodt

F. Cörvers

H. Heijke

J. van Thor

ROA-TR-2011/1

februari 2011

Research Centre for Education and the Labour Market Maastricht University

P.O. Box 616, 6200 MD Maastricht, The Netherlands

$\mathrm{T}+31433883647 \mathrm{~F}+31433884914$

secretary-roa-sbe@maastrichtuniversity.nl www.roa.nl 


\section{Voorwoord}

Het voorliggende onderzoek is uitgevoerd in het kader van het onderzoeksprogramma van het landelijk expertisecentrum beroepsonderwijs (ecbo). Het onderzoek sluit aan bij het deelprogramma 'De economische functie van het beroepsonderwijs' binnen de programmalijn 'Beroepsonderwijs en kenniseconomie' van ecbo. De auteurs danken ecbo voor de medewerking en het constructieve commentaar op een eerdere versie van het rapport. 



\section{Samenvatting}

In dit rapport is onderzocht hoe afstandsgevoelig jongeren in het voortgezet onderwijs (vmbo/havo) zijn bij de overgang naar het middelbaar beroepsonderwijs (mbo) en welke invloed de ruimtelijke spreiding van mboopleidingen over opleidingslocaties heeft op de keuze voor één van de sectoren techniek, economie of zorg. Voor het onderzoek is gebruik gemaakt van gegevens over ruim 15.600 eerstejaarsleerlingen van het mbo in de regio Noord- en Midden-Limburg en de oostelijke helft van Noord-Brabant. Daarbij is gebruik gemaakt van de administratieve leerlingbestanden van de vijf ROC's die hun hoofdvestiging hebben in dit gebied. ${ }^{1}$ Leerlingen kunnen kiezen uit 31 verschillende opleidingslocaties van deze ROC's. Op elk van deze locaties wordt ofwel één opleidingssector aangeboden (techniek, economie of zorg) ofwel een combinatie van deze sectoren. Op 19 van de 31 opleidingslocaties worden er technische opleidingen aangeboden, 17 locaties bieden economische opleidingen aan, en 15 locaties bieden zorgopleidingen aan.

De keuze voor een studie wordt bepaald door zowel persoonlijke factoren als omgevingsfactoren. Tot de persoonlijk factoren worden onder andere gerekend geslacht, herkomst en leeftijd. Voorbeelden van omgevingsfactoren zijn kwaliteit, imago en grootte van de opleiding(slocatie), de invloed van vrienden, ouders en kennissen, maar ook de afstand en bereikbaarheid van de opleidingslocatie. De invloed van de achtergrondkenmerken en de afstandsgevoeligheid van mbo-leerlingen op de keuze van een opleidingslocatie en -sector wordt in deze studie geschat aan de hand van logistische regressiemodellen.

Over de invloed van reisafstand op de keuze voor een opleiding is slechts weinig bekend uit de literatuur. Duidelijk is wel dat de kans op geografische mobiliteit (i.e. pendelen of verhuizen) kleiner is als de afstand waarop deze betrekking heeft groter is. Deze afstandsgevoeligheid of -afhankelijkheid wordt in de Angelsaksische economische literatuur aangeduid met de term 'distance deterrence'. In het algemeen laten empirische studies een negatief verband zien tussen afstand en de keuze voor een opleidingslocatie. De ruimtelijke spreiding van de opleidingslocaties kan dus van invloed zijn op de keuze voor een bepaalde opleiding. In de empirische studies wordt vaak buiten beschouwing gelaten dat er meerdere onderwijsinstellingen in de omgeving van de onderzochte school of universiteit liggen. Deze zogenaamde 'intervening opportunities' gelden als mogelijke alternatieven die het keuzeproces van leerlingen kunnen beïnvloeden. Aangezien de alternatieve opleidingslocaties in dit rapport als keuzemogelijkheden meegenomen worden, levert de empirische analyse een bijdrage aan de bestaande literatuur.

Uit ons onderzoek komt naar voren dat de kans om voor een opleidingssector te kiezen afneemt wanneer de afstand tot de dichtstbijzijnde, alsook de afstand tot de op één na dichtstbijzijnde opleidingslocatie waar deze sector wordt aangeboden groter is. Dit effect is echter niet aantoonbaar voor de op twee na dichtstbijzijnde opleidingslocatie waar een sector aangeboden wordt. We leiden hieruit af dat daarbij andere voor ons niet direct waarneembare factoren een rol spelen. Bij de keuze van locaties die verder weg gelegen zijn letten leerlingen wellicht vaker op de kwaliteit van de opleiding en de bereikbaarheid van de locatie. Ook kunnen leerlingen kiezen voor een specifieke richting binnen een sector (bijv. werktuigbouwkunde binnen techniek), waarvoor ze bereid zijn verder te reizen.

Een belangrijke conclusie van het onderzoek is dat techniekleerlingen minder afstandsgevoelig zijn dan economie- en zorgleerlingen. Als de afstand die een gemiddelde techniekleerling moet afleggen naar de voor de leerling dichtstbijzijnde locatie waar techniek wordt aangeboden met één kilometer toeneemt, neemt de kans dat de leerling voor een technische opleiding zal kiezen met 0,3\% af. De kans dat een leerling voor techniek kiest neemt dus met $6 \%$ af als deze leerling 20 kilometer verder weg woont van de dichtstbijzijnde technieklocatie. Voor zowel economieleerlingen als leerlingen uit de zorg is het effect groter. Voor hen geldt dat iedere kilometer

1. Het gaat om respectievelijk ROC Gilde Opleidingen, ROC Eindhoven, ROC Ter AA, ROC Koning Willem I College en ROC De Leijgraaf. 
die zij verder van de dichtstbijzijnde locatie wonen de kans voor de keuze voor economie of zorg 0,9\% doet afnemen. Als zij 20 kilometer verder wonen van de dichtstbijzijnde locatie waar deze opleidingen worden aangeboden dan neemt de kans om voor respectievelijk economie of zorg te kiezen met bijna een vijfde af (18\%). Leerlingen die kiezen voor techniek laten zich doorgaans dus minder leiden door afstand. Zij kiezen bijvoorbeeld vaker voor een technische studie vanwege een sterke intrinsieke motivatie.

De resultaten laten verder zien dat een andere regionale spreiding van opleidingen er toe kan leiden dat leerlingen voor een alternatieve sector kiezen. Wanneer technieklocaties verder weg gelegen zijn kiezen leerlingen doorgaans vaker voor economie. Tevens blijkt dat wanneer economielocaties verder weg gelegen zijn, leerlingen eerder voor een zorgopleiding zullen kiezen. Wanneer de afstand tot zorglocaties toeneemt, kiezen leerlingen vaker voor economie en in mindere mate voor techniek.

Voor beleidsmakers kan het van belang zijn rekening te houden met de hier gevonden resultaten. Door de daling van het aantal leerlingen in veel regio's in Nederland zullen meerdere ROC's noodgedwongen een aantal kleinere opleidingslocaties moeten sluiten of samenvoegen met andere locaties. Ook samenwerking tussen ROC's kan daarbij een optie zijn. De concentratie van opleidingen kan consequenties hebben voor de deelname van leerlingen aan de verschillende opleidingssectoren. Bij de strategische keuze betreffende de spreiding van opleidingen over locaties dient zowel rekening te worden gehouden met de keuzes van leerlingen voor bepaalde sectoren onder invloed van de dagelijkse afstand die zij moeten overbruggen van thuis naar school, als het behoud van leerlingen voor de ROC's. 


\section{Inleiding}

In hoeverre laten leerlingen in het voortgezet onderwijs zich bij hun keuze voor een opleiding in het middelbaar beroepsonderwijs beïnvloeden door afstand? Kiezen leerlingen eerder voor een niet-technische opleiding wanneer zij verder af wonen van een opleidingslocatie waar techniek wordt aangeboden? Hoe wordt hun keuze beïnvloed door de ruimtelijke spreiding van alternatieve dicht bij huis gelegen opleidingslocaties? Als de afstand tot een school groter is, kiest een leerling dan sneller voor een opleiding aan een andere school? En laten vrouwen of allochtonen zich bij hun keuze meer of minder beïnvloeden door afstand dan mannen en autochtonen? Deze vragen worden in het voorliggende rapport beantwoord. Op deze wijze wordt in kaart gebracht hoe leerlingen zich laten beïnvloeden door afstand bij hun keuze voor een school, maar in het bijzonder voor een specifieke opleidingssector, in het middelbaar beroepsonderwijs.

Uit onderzoek van Cörvers et al. (2005) blijkt dat er verschillende factoren zijn die een rol spelen bij de keuze voor een studie en school in het mbo. Zo vinden leerlingen het bijvoorbeeld belangrijk dat een school dicht bij huis gelegen is en dat deze goed bereikbaar is met het openbaar vervoer. In dit rapport wordt de afstandsgevoeligheid bij de studiekeuze van leerlingen nader onderzocht. Het gaat om eerstejaarsleerlingen van het mbo die kiezen voor techniek, economie of zorg. De kernvragen van dit rapport zijn hoe afstandsgevoelig jongeren in het voortgezet onderwijs (vmbo/havo) zijn bij de overgang naar het middelbaar beroepsonderwijs (mbo) en welke invloed de ruimtelijke spreiding van mbo-opleidingen over opleidingslocaties heeft op de keuze voor een bepaalde opleidingssector.

In het onderzoek schatten we de invloed van reisafstand op de keuze voor een sector. Het lijkt voor de hand te liggen dat er een negatief effect is van reisafstand op de keuze voor een opleidingslocatie. Reisafstand schrikt, zo neemt men algemeen aan, leerlingen af om te kiezen voor een opleiding op een bepaalde locatie. Deze afstandsgevoeligheid staat bekend als 'distance deterrence'. De ruimtelijke spreiding van het aanbod van opleidingen kan dus van invloed zijn op de keuze voor een bepaalde opleiding. In de ons bekende empirische studies over dit onderwerp wordt buiten beschouwing gelaten dat er meerdere onderwijsinstellingen in de omgeving van de onderzochte school of universiteit liggen. Deze zogenaamde 'intervening opportunities' gelden als mogelijke alternatieven die het keuzeproces van leerlingen kunnen beïnvloeden. In dit rapport worden de alternatieve opleidingslocaties met de aldaar aangeboden opleidingen wel als keuzemogelijkheden meegenomen.

Voor het onderzoek is gebruik gemaakt van de leerlingbestanden van de vijf grote Regionale Opleidingscentra (ROC's) in de regio Noord- en Midden-Limburg en de oostelijke helft van Noord-Brabant. Het gaat om alle ROC's die hun hoofdvestiging hebben in de COROP-gebieden Noordoost-Noord-Brabant, Zuidoost-Noord-Brabant, Noord-Limburg en Midden-Limburg. Daarnaast zijn de leerlingbestanden van een kleine nevenvestiging in Sittard-Geleen meegenomen in de analyse. In totaal gaat het om ruim 15.600 eerstejaarsleerlingen van het mbo. In figuur 1.1 wordt een indruk gegeven van de spreiding van de opleidingslocaties in het gebied. De figuren in bijlage I bij dit rapport geven voor elk van de opleidingssectoren techniek, economie of zorg weer, in welke gemeenten deze opleidingen aangeboden worden. De grootte van de symbolen in de figuren in de bijlage geeft daarbij aan of er per gemeente sprake is van één of meerdere opleidingslocatie(s) waar die sector wordt aangeboden. 
Gemeentes met ten minste één opleidingslocatie van de vijf ROC's die hun hoofdvestiging in oostelijk Noord-Brabant of Noorden Midden-Limburg hebben

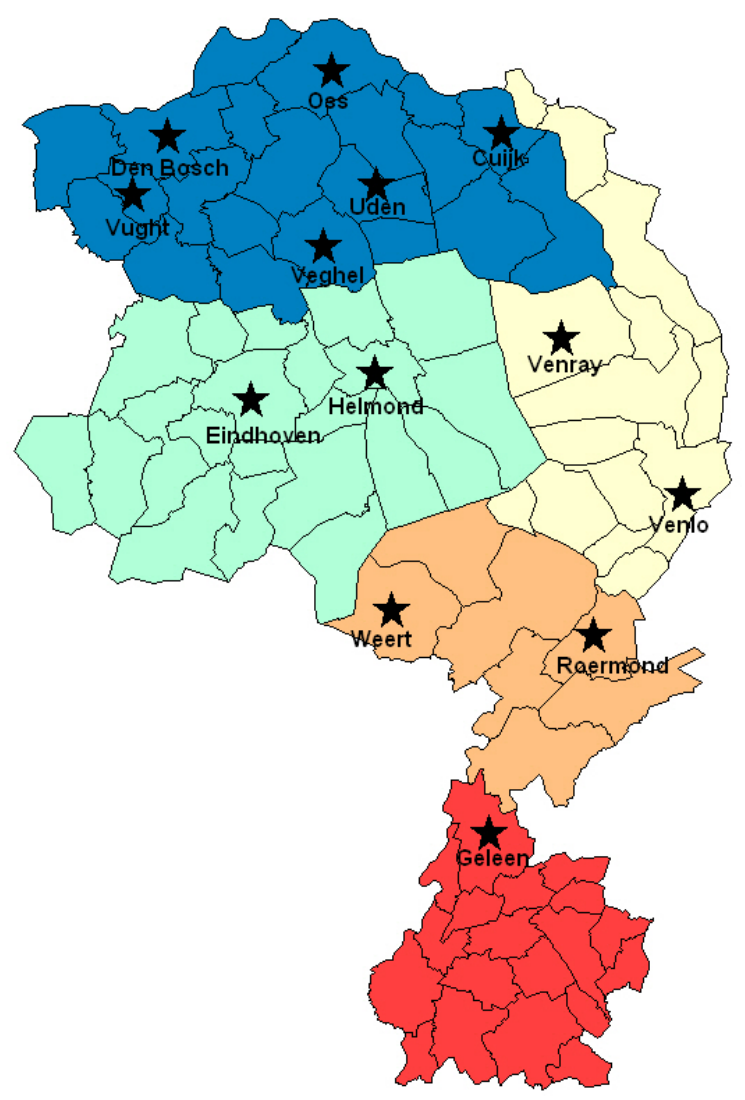

De invloed van de achtergrondkenmerken en de afstandsgevoeligheid van mbo-leerlingen op de keuze van een sector en een opleidingslocatie wordt met logistische modellen geschat. De achtergrondkenmerken van de leerlingen hebben onder meer betrekking op geslacht, leeftijd, herkomst en gevolgde vooropleiding en zijn opgenomen in de bovengenoemde (administratieve) leerlingbestanden. De keuze van een opleiding binnen techniek, economie of zorg en de keuze voor een opleidingslocatie binnen de regio is tevens afhankelijk van de reisafstanden tot de potentiële locaties van de te kiezen opleidingen. De dataset van administratieve gegevens over leerlingen is daartoe verrijkt met gegevens over de ruimtelijke keuzemogelijkheden voor de individuele leerlingen in een regio. De inzichten uit het onderzoek kunnen worden gebruikt bij de inschatting van de effecten van een ruimtelijke aanpassing van het opleidingenaanbod van ROC's op de deelname aan bepaalde, bijvoorbeeld technische, opleidingen.

De opbouw van dit rapport is als volgt. In hoofdstuk 2 wordt een overzicht gegeven van de relevante literatuur met betrekking tot de afstandsgevoeligheid bij de keuze voor een opleiding en opleidingslocatie. In hoofdstuk 3 wordt de gebruikte dataset gedetailleerd beschreven, wordt de gemiddelde afstand tot de opleidingslocatie gepresenteerd voor verschillende groepen en wordt besproken welk deel van de leerlingen kiest voor de dichtstbijzijnde tot en met de meest verafgelegen opleidingslocatie. Hoofdstuk 4 geeft de empirische analyses weer, en hoofdstuk 5 bevat de belangrijkste conclusies. 


\section{Literatuuroverzicht}

Over de invloed van reisafstand op de keuze voor een opleidingssector is slechts weinig bekend uit de economische literatuur. Dit laatste is juist onderwerp van de empirische analyse in hoofdstuk 4 . In de eerste paragraaf van dit hoofdstuk wordt ingegaan op de schaarse studies waarin de invloed van reisafstand op de studiekeuze is onderzocht. In de tweede paragraaf komt de invloed van afstand op de keuze van een opleidingslocatie door individuen aan de orde. In de studies op dit terrein gaat het er meestal om hoe afstand de verhuisbeslissing beïnvloedt in samenhang met de keuze voor een universitaire studie. Hoewel het in het voorliggende onderzoek voornamelijk gaat om de pendelbeslissing van eerstejaarsleerlingen van het mbo in relatie tot de keuze voor een sector, lijkt ons deze literatuur hier toch van belang.

\subsection{Invloed van afstand op de studiekeuze}

Volgens de economische theorie kiezen leerlingen een opleidingsinstituut op basis van de waarde die zij hieraan toekennen (bijv. Vrontis, Thrassou \& Melanthiou (2007). Tijdens het beslissingsproces bij het vinden van een opleiding kunnen verschillende factoren de uiteindelijke keuze van toekomstige studenten beïnvloeden. Zo kunnen studenten voor een school kiezen als deze de opleiding biedt, die zij het meest interessant vinden, hoog aangeschreven staat, kwalitatief hoogwaardig onderwijs biedt, goede kansen op werk biedt, kort bij huis gelegen is, waarover familie positief gestemd is en waar vrienden ook voor kiezen (Soutar \& Turner, 2002). De keuze van leerlingen voor een mbo-opleiding na het afronden van het voortgezet onderwijs (vmbo of havo) wordt bepaald door hun preferenties ten aanzien van de genoemde factoren. Het gaat dus om de waarde die een leerling toekent aan verschillende aspecten die met de keuze voor een bepaalde opleiding gepaard gaan.

Daarnaast kunnen ook restricties een rol spelen bij de opleidingskeuze, zoals de moeilijkheidsgraad van een opleiding, de studiekosten en de afstand tot de opleidingslocatie. Deze restricties vertegenwoordigen een negatieve waarde bij de opleidingskeuze. Volgens de economische theorie kent een leerling aan elk van de genoemde aspecten (impliciet) een positieve of negatieve waarde toe bij de opleidingskeuze (zie bijv. Borghans, 1999 en Borghans \& De Steur, 1999). De studiekeuze is in de economische theorie dus een rationeel proces, waarbij ook het vermogen van leerlingen om zich een beeld te vormen van de toekomstige situatie en de consequenties van de keuze voor een opleiding een rol speelt. ${ }^{2}$ De opleiding die voor een bepaalde leerling het grootste positieve verschil genereert tussen verwachte kosten en baten wordt door de leerling gekozen.

Uit onderzoek door Bloemen \& Dellaert (2000) blijkt dat leerlingen in het voortgezet onderwijs (vmbo en havo/vwo) zich vooral laten leiden door hoe interessant ze een opleiding vinden, en in welke mate ze in het beroep dat met de opleiding wordt geassocieerd iets voor andere mensen of voor de maatschappij kunnen betekenen. De intrinsieke motivatie speelt dus de belangrijkste rol bij de studiekeuze. De kosten van het volgen van een bepaalde opleiding spelen daarentegen nauwelijks een rol. Leerlingen houden bij hun studiekeuze wel rekening met de kans op werk, de arbeidsvoorwaarden en de carrièreperspectieven. Het verwachte loon en de kans op werk zijn relatief belangrijk voor mannen en voor leerlingen die kiezen voor economie en informatica. Een groter loonverschil of een groter verschil in de arbeidsmarktsituatie tussen twee opleidingen kan echter slechts in beperkte mate de keuze tussen deze opleidingen veranderen. Vrouwen en leerlingen die kiezen voor de zorg of het onderwijs waarderen juist het helpen van andere mensen en de bijdrage aan de maatschappij relatief hoog. In het kader van het voorliggende onderzoek is vooral van belang dat zij concluderen dat een reisafstand tot $30 \mathrm{~km}$ van thuis naar school nauwelijks invloed heeft op de studiekeuze. Bij een reisafstand van $80 \mathrm{~km}$ of langer is deze invloed wel significant aanwezig. Voor de tussenliggende afstanden is er niet getoetst hoe groot de invloed is.

2. Daarbij ligt de relatie met de percepties van de leerlingen voor de hand. Hier ligt in de psychologische literatuur de nadruk op. Vooral bij gebrek aan volledige informatie spelen beeldvorming en imago een rol in het keuzeproces. 
Het onderzoek van Bloemen \& Dellaert (2000) is gebaseerd op zogenaamde 'stated preferences'. Dit zijn door individuen aangegeven voorkeuren als een situatie zich zou voordoen. Het gaat dus niet om de feitelijke keuze van individuen, maar om de keuze die men aangeeft in een beperkt aantal, vaak hypothetische situaties, te zullen maken. Dit in tegenstelling tot de 'revealed preferences' waarin de feitelijk gemaakte keuzes centraal staan. Deze hebben in het voorliggende rapport betrekking op de werkelijke opleidingskeuze en de werkelijke afstand die leerlingen reizen van thuis naar school. Hier zullen we kijken naar hoe het feitelijk gedrag van leerlingen met betrekking tot de keuze voor een opleidingslocatie afhangt van de spreiding van opleidingslocaties en het opleidingenaanbod op deze locaties. Een ander voordeel van dit onderzoek met 'revealed preferences' is dat veel preciezer kan worden nagegaan wat de invloed van reisafstand is dan bij 'stated preferences'.

Virtanen \& Väänänen (2010) onderzoeken hoe het regionale opleidingsaanbod de keuze voor een opleiding beïnvloedt in Finland. Finse leerlingen zijn wettelijk verplicht onderwijs te volgen tot zij zestien jaar oud zijn. Hierna stromen zij door naar het hoger secundair onderwijs, waarbij zij de keuze hebben tussen algemeen vormend onderwijs en beroepsonderwijs. Binnen het beroepsonderwijs hebben leerlingen de keuze uit zeven verschillende sectoren. In dit onderzoek wordt onder meer onderzocht wat de invloed is van afstand op de keuze voor één van deze acht alternatieve opleidingsmogelijkheden. Deze studie toont aan dat het regionale opleidingsaanbod significant van invloed is op deze opleidingskeuze. Naarmate de afstand tot de dichtstbijzijnde locatie waar een bepaalde opleiding aangeboden wordt toeneemt, neemt de kans dat een leerling voor die opleiding kiest significant af. Tevens vinden zij dat wanneer de afstand naar de dichtstbijzijnde locatie waar een bepaalde opleiding wordt aangeboden toeneemt, leerlingen vaker voor een opleiding in een andere sector kiezen. Voor jongens zijn de geschatte effecten daarbij groter dan voor meisjes.

De administratieve data van eerstejaarsleerlingen in het mbo zijn eerder gebruikt in het onderzoek van Cörvers et al. (2005), waarin bovendien enquêtegegevens van een beperkt aantal leerlingen (techniek en economie, ongeveer 200 leerlingen) zijn gebruikt om de informatie van de 'revealed preferences' te combineren met die van de 'stated preferences'. $\mathrm{Er}$ is in dit onderzoek echter geen verklarend model geschat met de administratieve data, hetgeen in het voorliggende onderzoek wel is gebeurd. Uit Cörvers et al. (2005) blijkt dat leerlingen die wonen in gebieden die verder weg van een ROC liggen, relatief vaak voor een technische opleiding kiezen. Leerlingen die in plaatsen rondom de ROC's wonen, kiezen daarentegen relatief vaak voor een economie- of een zorgopleiding. Dit verband blijft gehandhaafd als er gecontroleerd wordt voor allerlei andere variabelen zoals geslacht, leeftijd, herkomst, niveau, ROC, etc. Veel leerlingen die voor techniek kiezen lijken dus bereid te zijn om een grotere afstand te overbruggen dan leerlingen van andere sectoren. De 'stated preferences' van leerlingen laten tevens zien dat een verbreding van het opleidingenaanbod op een bepaalde locatie - bijvoorbeeld economie naast techniek - relatief veel leerlingen die in eerste instantie voor een technische studie kiezen zou kunnen overhalen om te kiezen voor een economische opleiding, terwijl dit andersom veel minder het geval lijkt te zijn.

\subsection{Invloed van afstand op de migratiebeslissing}

In de economische literatuur wordt afstand als verklarende factor gezien bij de beslissing om te verhuizen (e.g. Greenwood, 1975; Leppel, 1993; Sá, Florax \& Rietveld, 2004; Frenette, 2006; Spiess \& Wrohlich, 2008). Daarbij wordt de kans op verhuizen kleiner als de afstand waarop de verhuisbeslissing betrekking heeft groter is. Deze afstandsafhankelijkheid wordt ook wel aangeduid met de term 'distance deterrence'. Greenwood noemt drie mogelijke verklaringen voor de afnemende bereidheid om te verhuizen als de afstand tot de nieuwe locatie toeneemt, namelijk hogere psychische kosten (bijv. minder familiebezoek), grotere transportkosten (bijv. hogere verhuiskosten) en hogere informatiekosten (bijv. grotere onbekendheid met omgeving). Als er minder informatie beschikbaar is over de nieuwe locatie (woongenot, cultuur, werkgever, opleiding, etc.) neemt de onzekerheid over de keuze om te verhuizen toe.

In het algemeen worden twee hoofdoorzaken onderscheiden voor menselijke migratie (e.g. Mixon \& Hsing, 1994; Baryla \& Dotterweich, 2001; Sá, Florax, \& Rietveld, 2004). Allereerst wordt verhuizen vanuit het oogpunt van de human capital theorie verklaard als investering in menselijk kapitaal. Volgens de human capital theorie besluit 
iemand om te verhuizen met het oog op hogere toekomstige inkomsten door bijvoorbeeld een verbetering van de arbeidsmarktperspectieven. De human capital theorie is gebaseerd op o.a. Becker $(1964 ; 1975)$ en heeft betrekking op het investeringskarakter van een beslissing, waarbij de baten zich pas op de langere termijn manifesteren. Daarnaast wordt verhuizen vaak verklaard vanuit de consumptietheorie, wat betekent dat mensen verhuizen omdat ze op zoek zijn naar meer woongenot en betere lokale voorzieningen, bijvoorbeeld wat betreft parken, recreatiemogelijkheden of culturele activiteiten (Sá, Florax, \& Rietveld, 2004). De consumptietheorie verklaart menselijke migratie, in tegenstelling tot de human capital theorie, door te wijzen op directe opbrengsten en voordelen op de korte termijn.

Het verhuizen als gevolg van de studiekeuze kan gezien worden als onderdeel van deze algemene migratietheorieën en wordt doorgaans ook verklaard vanuit het perspectief van hetzij investeringen in human capital hetzij consumptiegronden (e.g. Tuckman, 1970; Mixon \& Hsing, 1994; Baryla \& Dotterweich, 2001; Sá, Florax, \& Rietveld, 2004). Zo kunnen studenten verhuizen omdat zij een studie willen volgen waarvan zij in de toekomst hogere inkomsten verwachten of waarmee zij hun arbeidsmarktpositie denken te versterken. Consumptiemotieven die voor studenten van invloed kunnen zijn op de keuze om te verhuizen zijn bijvoorbeeld het levendigere studentenleven of de betere recreatiemogelijkheden die een andere stad te bieden heeft.

Wanneer onderwijs gezien wordt als investering in human capital, betekent dit dat leerlingen voor een opleiding kiezen omdat deze uiteindelijk de hoogste netto contante waarde, het verschil tussen de contante waarde van totale baten en kosten, oplevert (DesJardins, Dundar \& Hendel, 1999). De totale baten verwijzen naar de eerder genoemde verwachte toekomstige inkomsten en verbeterde carrièremogelijkheden, terwijl de totale kosten van educatie uitgesplitst kunnen worden in directe en indirecte kosten. Directe kosten behelzen boeken, les- of collegegelden, reiskosten en dergelijke, terwijl gederfde inkomsten tijdens de studie als indirecte kosten aangemerkt worden. De optimale vraag naar educatie wordt dan bepaald door een combinatie van deze directe kosten, gederfd inkomen en verwacht toekomstig inkomen (Becker, 1964; Huijsman et al., 1986). Vanuit de human capital theorie bezien kan de beslissing van een leerling om zich geografisch te verplaatsen van en naar zijn opleidingslocatie als een investeringsbeslissing beschouwd worden. Leerlingen doen deze opofferingen met het oog op betere arbeidsmarktperspectieven en hogere toekomstige salarissen. Volgens de human capital theorie zullen leerlingen die meer in zichzelf willen investeren eerder bereid zijn om dagelijks een grotere afstand af te leggen (pendelen) of om op kamers te gaan wonen.

Vaak wordt in dit verband ook gewezen op aspecten van de consumptietheorie die van invloed kunnen zijn op de keuze voor een bepaalde opleiding (e.g. Tuckman, 1970; Schaafsma, 1976; Huijsman et al., 1986; Baryla \& Dotterweich, 2001; Sá, Florax, \& Rietveld, 2004). Uitgaande van de consumptietheorie kan het verhuizen als gevolg van de keuze voor een opleiding verklaard worden door 'quality-of-life' verbeteringen waardoor ook nietgeldgerelateerde aspecten een rol spelen bij deze vorm van verhuizen (Baryla \& Dotterweich, 2001). Verhuizen of pendelen naar een ander gebied biedt mensen bepaalde voordelen, waardoor zij eventueel zelfs genoegen kunnen nemen met lagere inkomsten. Tuckman (1970) noemt onder meer de sfeer op school en de locatie van de school als mogelijke voorbeelden die voor studenten zwaarder kunnen wegen dan reis- of vestigingskosten. Sá et al. (2004) wijzen in dit verband op het verhuizen naar een stad met bijvoorbeeld aantrekkelijke voorzieningen en vrijetijdsfaciliteiten. Volgens Tuckman (1970) kiezen sommige leerlingen op basis van deze motieven zelfs liever voor een verderaf gelegen school dan voor een vergelijkbare school die korter bij huis gelegen is. Het onderzoek van Tuckman wordt doorgaans beschouwd als de voorbeeldstudie op het gebied van studentenmigratie (Baryla \& Dotterweich, 2001). Volgens deze Amerikaanse studie is de kans dat studenten verhuizen groter als ze in een gebied wonen met een hoog inkomen per hoofd of in een gebied waar meer lesgeld betaald moet worden. In de literatuur gaat het daarbij doorgaans om verhuizen als gevolg van de keuze voor een studie in het hoger onderwijs.

Tot op heden zijn empirische studies met betrekking tot het verband tussen afstand en de toegankelijkheid van (postsecundair) onderwijs echter schaars (Sá, Florax \& Rietveld 2004; Frenette, 2006). In verschillende onderzoeken wordt, bij gebrek aan een afstandsvariabele, een dummy opgenomen die aangeeft of iemand in 
een ruraal dan wel urbaan gebied woonachtig is, maar dit hoeft volgens Frenette niet per definitie te betekenen dat iemand die in een stedelijk gebied woont ook daadwerkelijk korter bij een opleidingslocatie woont. In het algemeen laten empirische studies een negatief verband zien tussen afstand en de keuze voor een opleidingslocatie (DesJardins, Dundar \& Hendel, 1999). Ook Sá, Florax \& Rietveld (2004), die een literatuuroverzicht maken van studies die de vraag naar hoger onderwijs verklaren, concluderen dat de resultaten van bijna alle bestudeerde empirische studies wijzen op het 'distance deterrence' effect.

Frenette (2006) onderzoekt de invloed van afstand op universitaire participatie in Canada en maakt daarbij onderscheid tussen drie groepen studenten die tijdens hun middelbare schoolperiode woonden op een afstand van respectievelijk $0-40 \mathrm{~km}, 40-80 \mathrm{~km}$ of $80 \mathrm{~km}$ of meer ten opzichte van de dichtstbijzijnde universiteit. Hij concludeert dat de kans dat studenten die op grote afstand van een universiteit wonen (i.e. buiten pendelafstand) kiezen voor een universitaire studie, aanzienlijk kleiner is dan voor studenten die op pendelafstand wonen. Als studenten verder dan $40 \mathrm{~km}$ van een universiteit wonen, neemt de kans dat zij kort na hun middelbare schoolperiode kiezen voor een universitaire studie met $25 \%$ af vergeleken met studenten die binnen een afstand van $40 \mathrm{~km}$ wonen. Voor studenten die op een afstand van meer dan $80 \mathrm{~km}$ wonen is de kans dat zij voor een universitaire studie kiezen $68 \%$ ten opzichte van studenten die binnen $40 \mathrm{~km}$ van een universiteit wonen.

Als verklaring wijst Frenette op het kostenvoordeel voor studenten die op pendelafstand wonen. Zij kunnen thuis blijven wonen en hebben derhalve geen extra woon- en verhuiskosten. Het zijn daarbij met name studenten uit gezinnen met een lager inkomen die beperkt worden in de vrijheid van hun studiekeuze naarmate de reisafstand toeneemt. Laatstgenoemde groep kan zich deze extra kosten namelijk moeilijker veroorloven.

Volgens Sá, Florax en Rietveld (2004) speelt ruimtelijke spreiding van de opleidingslocaties een belangrijke rol bij de keuze van leerlingen voor een bepaalde opleiding. In de praktijk betekent dit dat leerlingen zich tijdens het keuzeproces bij het zoeken naar een geschikte opleiding kunnen laten beïnvloeden door de afstand tussen hun woning en de opleidingslocatie (i.e. 'distance deterrence'-effect). Hun resultaten verschillen per model, maar zij vinden telkens een significant negatieve invloed van afstand op de keuze om te gaan studeren aan een universiteit.

Volgens Leppel (1993) zijn studenten minder snel geneigd om voor een bepaalde school te kiezen naarmate de afstand tussen woonplaats en opleidingslocatie groter is. Leppel ziet vijf mogelijke verklaringen voor dit negatieve effect van afstand. Allereerst hebben studenten de beschikking over een geringere hoeveelheid informatie over een school naarmate de afstand toeneemt. Door de opkomst van internet en door de kleinere afstanden in Nederland zal dit argument hier echter minder van toepassing zijn. Ten tweede zullen de kosten steeds sterker toenemen bij een toenemende afstand. Als derde punt noemt Leppel dat voor studenten die een studie aan een verderaf gelegen school overwegen het aanbod van mogelijke opleidingslocaties ook zal toenemen. Om die reden zal de kans dat de student kiest voor die bepaalde opleidingslocatie afnemen. Ten vierde zijn er psychologische kosten aan afstand verbonden. Studenten kunnen zich minder op hun gemak voelen in plaatsen waar ze niet vertrouwd mee zijn vergeleken met een opleidingslocatie dichter bij huis. Een laatste verklaring voor de negatieve invloed van afstand bij de schoolkeuze is het feit dat studenten geneigd zijn om te kiezen voor een school in de naaste omgeving waar vrienden of ouders ook voor gekozen hebben, waardoor ze meer vertrouwd zijn met de betreffende onderwijsinstelling.

In de studie van Leppel (1993) wordt onderzoek gedaan naar het keuzegedrag van studenten die zijn ingeschreven op Widener University gelegen in Delaware County, Pennsylvania (Verenigde Staten). De afstand tussen woon- en opleidingslocatie wordt onderverdeeld in achtereenvolgens minder dan tien mijl, 10-25 mijl, 25 50 mijl, 50-100 mijl en meer dan 100 mijl. Studenten die binnen een straal van 10 mijl van de universiteit wonen, kiezen het vaakst voor een studie aan de betreffende universiteit. Studenten die respectievelijk tussen de tien en vijfentwintig mijl of tussen de vijfentwintig en vijftig mijl van de universiteit wonen, kiezen in vergelijking met de eerste groep minder snel voor een studie aan deze universiteit. Studenten uit de twee laatstgenoemde groepen kiezen daarentegen weer sneller voor deze universiteit dan studenten die nog verder weg wonen. Vooral interessant is het dat studenten die woonachtig zijn op een afstand van vijftig tot honderd mijl niet significant 
meer voor deze universiteit kiezen dan degenen die meer dan honderd mijl ver weg wonen. Vanaf een bepaalde afstand lijkt de negatieve invloed die afstand heeft op de beslissing van studenten om te verhuizen dus niet meer te beïnvloeden, aldus Leppel.

In de bovenstaande literatuur wordt vaak buiten beschouwing gelaten dat er meerdere universiteiten in de omgeving van de onderzochte universiteit liggen. Deze zogenaamde 'intervening opportunities' gelden als mogelijke alternatieven die het keuzeproces van leerlingen kunnen beïnvloeden. Volgens Stouffer (1940) geldt dat het aantal personen dat bij migratie van ' $A$ ' naar ' $B$ ' verhuist, direct evenredig is met de kansen die zich voor migranten voordoen in ' $\mathrm{B}$ ' en omgekeerd evenredig is met het aantal kansen dat zich voordoet tussen ' $A$ ' en ' $B$ '. Bij ons weten is de voorliggende studie dan ook één van de eerste waarin alternatieve opleidingslocaties als keuzemogelijkheden worden meegenomen bij het voorspellen van de opleidingskeuze.

\section{Beschrijvende analyse}

In de eerste paragraaf van dit hoofdstuk volgt een korte bespreking van de gebruikte dataset. In paragraaf 3.2 wordt vervolgens een uitgebreide analyse gegeven van de reisafstand die eerstejaarsleerlingen in het mbo afleggen naar school, gedifferentieerd naar sector (techniek, economie of zorg) en verschillende andere achtergrondkenmerken. Paragraaf 3.3 bevat een analyse van de verdeling van leerlingen over de alternatieve opleidingslocaties. In deze paragraaf wordt besproken welk deel van de leerlingen voor de dichtst bij huis gelegen school kiest, welk deel voor de op één na dichtstbijzijnde school kiest, enzovoorts. Tevens dragen we in dit hoofdstuk mogelijke verklaringen aan voor de gevonden verschillen in afstand.

\subsection{Dataset}

De dataset bevat gegevens over ruim 15.600 eerstejaars mbo-leerlingen die een studie volgen aan één van de vijf ROC's in het oosten van Noord-Brabant en het noorden en midden van Limburg. Het gaat om alle ROC's die hun hoofdvestiging hebben in de COROP-gebieden Noordoost-Noord-Brabant, Zuidoost-Noord-Brabant, NoordLimburg en Midden-Limburg. ${ }^{3}$ Daarnaast is er een kleine nevenvestiging in Sittard-Geleen van één van de ROC's (Gilde Opleidingen met ruim 100 eerstejaarsleerlingen) welke is meegenomen in de analyse. Daarentegen zijn er ook leerlingen die een mbo-opleiding volgen bij een school in één van deze COROP-gebieden, maar die niet in het onderzoek betrokken zijn. Het betreft leerlingen van nevenvestigingen van ROC's die hun hoofdvestiging buiten het COROP-gebied hebben (bijv. De Rooi Pannen), leerlingen van groene opleidingen (bijv. AOC Limburg/Citaverde en Helicon opleidingen), en leerlingen van kleinere of niet-regulier bekostigde opleidingen (bijv. vakscholen voor communicatie, schilderen, grafische techniek). Doordat echter alle eerstejaarsleerlingen van de vijf grote ROC's zijn opgenomen in de dataset, is het overgrote deel van de eerstejaarsleerlingen van het mbo in het onderzoeksgebied vertegenwoordigd. ${ }^{4}$

Figuur 3.1 geeft de leerlingenverdeling over de vijf ROC's weer. In de legenda wordt per ROC tevens de plaats van de hoofdvestiging weergegeven. Van de totale groep eerstejaars mbo-leerlingen volgt bijna dertig procent een studie aan ROC Gilde Opleidingen en ruim een kwart een studie aan ROC De Leijgraaf. De groep leerlingen die een opleiding volgt aan ROC Ter AA is met $6,4 \%$ het kleinst. Laatstgenoemde groep bestaat echter nog altijd uit ongeveer 1.000 leerlingen.

3. Aangezien leerlingen in de praktijk natuurlijk ook voor scholen buiten het onderzoeksgebied kunnen kiezen, zijn er in de empirische analyses gevoeligheidsanalyses uitgevoerd. Om de werkelijkheid na te bootsen is het onderzoeksgebied kleiner gemaakt. Op deze wijze kan een beeld gevormd worden van de leerlingen die in het 'hart van deze regio' naar school gaan (i.e. Helmond, Veghel, Uden en Venray). De resultaten van deze analyses wijken echter niet significant af van de resultaten voor de hele regio.

4. Zie voor meer details het onderzoek van Cörvers et al. (2005). 
De gebruikte dataset van leerlingengegevens is tot stand gekomen door de verschillende door de ROC's aangeleverde bestanden te koppelen. De selecties uit de leerlingenadministraties zijn aan de hand van een gespecificeerde aanvraag van het ROA uitgevoerd door verschillende medewerkers van de ROC's. Het betreft de nieuwe instroom die geregistreerd was in het voorjaar van 2005 (schooljaar 2004/2005), excl. contractonderwijs en volwasseneneducatie. De onderwijsnummers die meerdere keren voorkwamen bij een ROC (door mutaties) werden verwijderd. Aan de hand van de beschikbare CREBO-codes zijn de SOI-codes (Standaard Onderwijsindeling van het CBS) vastgesteld. Deze waren noodzakelijk om te bepalen of leerlingen volgens het CBS een opleiding in techniek, economie of zorg volgden. Tot slot is van alle in Nederland wonende leerlingen met behulp van Google Maps de kortste afstand bepaald tussen de viercijferige postcodes van het woonadres van de leerlingen en de adres- en postcodegegevens van de opleidingslocatie.

De resultaten van de analyses hebben uitsluitend betrekking op leerlingen die in Nederland woonachtig zijn. Bij de regressieanalyses van hoofdstuk 4 is bij wijze van gevoeligheidsanalyse de dataset beperkt tot de leerlingen woonachtig in de bovengenoemde vier COROP-gebieden. Dit had echter geen significante invloed op de resultaten. Daarom is voor de beschrijving van de uitkomsten in dit en het volgende hoofdstuk de volledige dataset gebruikt van eerstejaarsleerlingen die in Nederland wonen en aan één van de genoemde vijf ROC's een opleiding volgen.

Figuur 3.1

Verdeling van leerlingen naar ROC

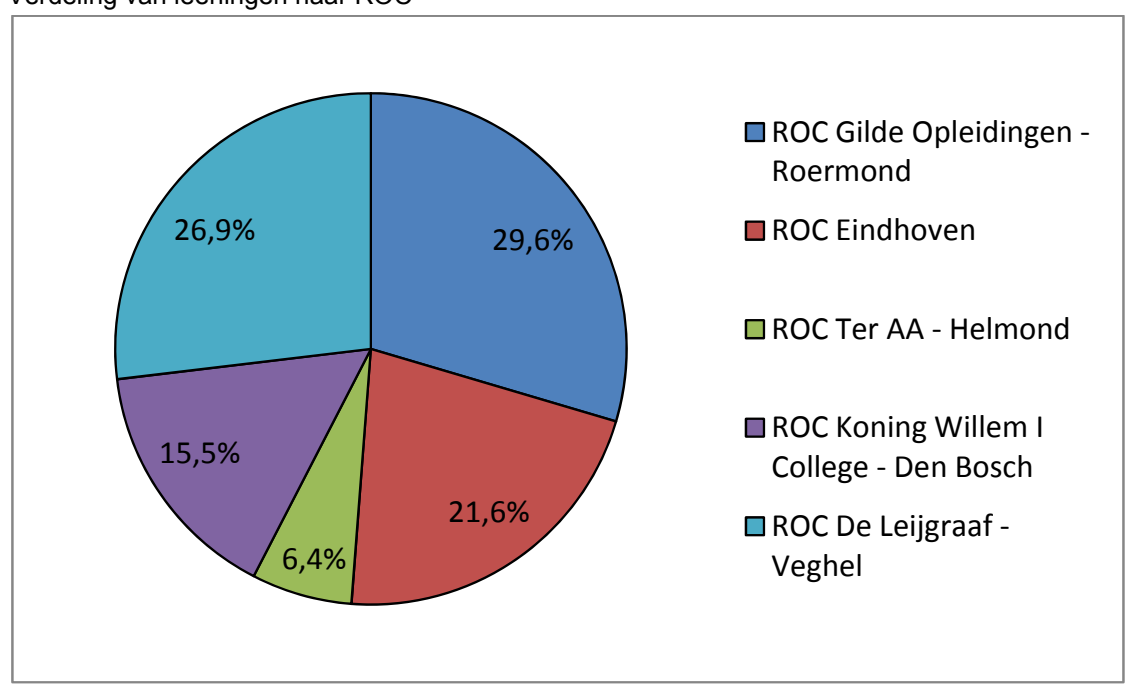

Helaas kan niet uit de administratieve data achterhaald worden of de eerstejaarsleerlingen nog bij hun ouders wonen of dat zij op zichzelf wonen. Als deze leerlingen namelijk nog thuis blijken te wonen, speelt de afstand tot de opleidingslocatie een rol bij de pendelbeslissing. Blijken leerlingen daarentegen juist op zichzelf te gaan wonen, dan speelt afstand voornamelijk een rol bij de verhuisbeslissing. Om toch een beeld te kunnen vormen van het aandeel leerlingen dat nog bij de ouders woont, is gekeken naar data van het SchoolverlatersInformatieSysteem van ROA. Hieruit blijkt dat (gediplomeerde) bol-leerlingen aanzienlijk vaker nog bij hun ouders wonen dan (gediplomeerde) bbl-leerlingen. Dit komt mede doordat bbl-leerlingen gemiddeld ook een stuk ouder zijn dan bol-leerlingen en daardoor vaker het ouderlijk huis verlaten. Aangezien ruim 6 op de 10 gediplomeerden van de hogere bol-niveaus nog bij de ouders blijkt te wonen, en ruim 7 op de 10 gediplomeerden van de lagere bol-niveaus, lijkt het aannemelijk dat dit aandeel onder eerstejaarsleerlingen nog 
hoger zal liggen. Dit betekent dat het grootste deel van deze leerlingen niet verhuisd is in het kader van hun studie. $^{5}$

Hoewel we in dit rapport uitsluitend geïnteresseerd zijn in de rol van afstand op het moment van de opleidingskeuze, dient hier met het oog op de volledigheid nog opgemerkt te worden dat uit de literatuur met betrekking tot voortijdige schoolverlaters naar voren komt dat er ook leerlingen zijn die er tijdens de studie pas achter komen dat de reisafstand hen opbreekt en dat zij om die reden alsnog stoppen met de opleiding. Met betrekking tot de data in dit rapport speelt dit probleem echter nauwelijks, omdat de data betrekking hebben op leerlingen die ingeschreven zijn in het voorjaar van 2005 (schooljaar 2004/2005), wat betekent dat leerlingen die het reizen niet op kunnen brengen waarschijnlijk al eerder in het schooljaar gestopt zijn.

Het onderzoeksgebied grenst aan zowel België als Duitsland. Vaak wordt verondersteld dat een behoorlijk aantal Nederlandse leerlingen ervoor kiest om de overstap te maken naar het Belgisch onderwijs. Uit het eerder verschenen rapport van Cörvers et al. (2005) kan echter aan de hand van cijfers van Cornielje (2004) geconcludeerd worden dat slechts een klein aantal Nederlandse leerlingen pas na het vmbo voor een (techniek)opleiding in België kiest. Nederlandse leerlingen die in België naar school gaan doen dit in het algemeen al vanaf de basisschool of meteen na de basisschool. Bij de keuze van gediplomeerde vmbo'ers voor een (techniek)opleiding is het Vlaamse onderwijs in de praktijk dan ook nauwelijks een alternatief.

\subsection{Reisafstand van leerlingen naar achtergrondkenmerk}

We zijn in dit rapport vooral geïnteresseerd in de rol die afstand speelt bij de keuze voor een opleidingslocatie in combinatie met de keuze voor een opleiding binnen de sectoren techniek, economie of zorg in de regio oostelijk Noord-Brabant en Noord- en Midden-Limburg. ${ }^{6}$ Tabel 3.1 verschaft inzicht in de gemiddelde afstanden tussen de woon- en opleidingslocatie van eerstejaars mbo-leerlingen. Een gemiddelde eerstejaars mbo-leerling in de dataset legt 19,2 kilometer af tussen de woon- en opleidingslocatie, terwijl de mediaan 13,8 kilometer is. Zoals blijkt uit de tabel worden de data tevens gespecificeerd naar opleidingssector, leeftijd, geslacht, herkomst, leerweg, mbo-niveau en richting van de vooropleiding.

Van de ruim 15.600 eerstejaars mbo-leerlingen, kiest bijna 3 op de 10 voor techniek (29,9\%), 35,6\% voor economie en $34,5 \%$ voor zorg. Uit tabel 3.1 blijkt dat techniekleerlingen, in vergelijking met leerlingen die kiezen voor de opleidingssectoren zorg en economie, gemiddeld de grootste afstand afleggen tussen hun woning en de opleidingslocatie (20,4 kilometer). Leerlingen die een economische opleiding volgen overbruggen op hun beurt weer een grotere afstand dan leerlingen die voor een zorgopleiding kiezen, respectievelijk 19,7 en 17,7 kilometer. In de praktijk betekent dit dat een leerling uit de sector techniek gemiddeld 0,7 kilometer verder reist naar zijn opleidingslocatie dan een leerling uit de sector economie en gemiddeld 2,7 kilometer verder reist dan een leerling uit de sector zorg.

5. In de empirische analyse zijn gevoeligheidsanalyses uitgevoerd, waarin alleen geselecteerd is op jongere leerlingen en daarnaast op leerweg. De resultaten verschilden echter niet significant.

6. Tenzij anders vermeld, bedoelen we met 'afstand' de enkele reisafstand tussen woon- en opleidingslocatie in kilometers. 
Tabel 3.1

Gemiddelde afstand van leerlingen tussen woon- en opleidingslocatie

Gemiddelde

afstand $(\mathrm{km})$

Totaal

19,2

Opleidingssector

Techniek 20,4

Economie $\quad 19,7$

Zorg $\quad 17,7$

Leeftijd

$15-20 \quad 17,0$

20-25 20,6

$25-30 \quad 32,5$

$30-35 \quad 29,0$

$>=35 \quad 32,0$

Geslacht

Man 20,3

Vrouw 18,0

Herkomst

Autochtoon $\quad 19,6$

Allochtoon $\quad 15,7$

Geslacht*herkomst

Mannelijke autochtoon $\quad 20,6$

Vrouwelijke autochtoon $\quad 18,4$

Mannelijke allochtoon $\quad 17,0$

Vrouwelijke allochtoon $\quad 14,4$

Leerweg

BOL 16,8

BBL 25,5

Mbo-niveau

mbo-niveau 1

mbo-niveau $2 \quad 19,0$

mbo-niveau $3 \quad 17,4$

mbo-niveau $4 \quad 18,9$

Vooropleiding

Algemeen 21,2

Techniek 18,4

Economie $\quad 15,4$

Zorg $\quad 17,0$

Groen $\quad 18,0$

De gemiddelde leeftijd van de eerstejaars mbo-leerlingen in de steekproef is 20,5 jaar en de mediaan is 18,0 jaar. Ongeveer tweederde van alle leerlingen in het bestand bevindt zich in de leeftijdscategorie 15 tot 20 jaar en 90 procent van alle leerlingen is jonger dan 25 jaar. Leerlingen uit de verschillende opleidingssectoren zijn gemiddeld genomen nagenoeg even oud, techniek: 20,3 jaar, economie: 20,1 jaar en zorg: 20,9 jaar. Wat betreft de afstand tussen woning en opleidingslocatie bestaan er aanzienlijke verschillen tussen jongere en oudere leerlingen. Leerlingen in de leeftijdscategorie 15 tot 20 jaar zoeken hun opleiding het kortst bij huis, terwijl leerlingen in de leeftijdscategorie 25 tot 30 jaar normaalgesproken bereid zijn de grootste afstand naar hun opleidingslocatie te overbruggen. In het algemeen kan gesteld worden dat jonge leerlingen (i.e. $<25$ jaar) vaker kiezen voor een opleidingslocatie die dichter bij huis gelegen is dan oudere leerlingen. 
De totale groep eerstejaars mbo-leerlingen in de dataset bevat iets meer mannen $(53,5 \%)$ dan vrouwen. In vergelijking met vrouwen zijn mannen bereid om een iets grotere afstand af te leggen naar hun opleidingslocatie. De gemiddelde afstand tussen de woon- en opleidingslocatie is voor mannelijke mbo-leerlingen (20,3 kilometer) gemiddeld 2,3 kilometer groter dan voor vrouwelijke mbo-leerlingen (18,0 kilometer).

Figuur 3.2 geeft het percentage vrouwelijke leerlingen weer per opleidingssector. Zoals verwacht brengt dit behoorlijke verschillen per opleidingssector aan het licht. Vrouwen zijn zwaar ondervertegenwoordigd in de technische opleidingen. Met betrekking tot de zorgopleidingen kan precies het omgekeerde geconcludeerd worden en hebben vrouwen juist ruim de overhand. In de sector economie is de verhouding tussen mannen en vrouwen iets gelijkmatiger, al volgen er meer mannen een economische opleiding $(58,6 \%)$.

Figuur 3.2

Percentage vrouwelijke leerlingen per opleidingssector

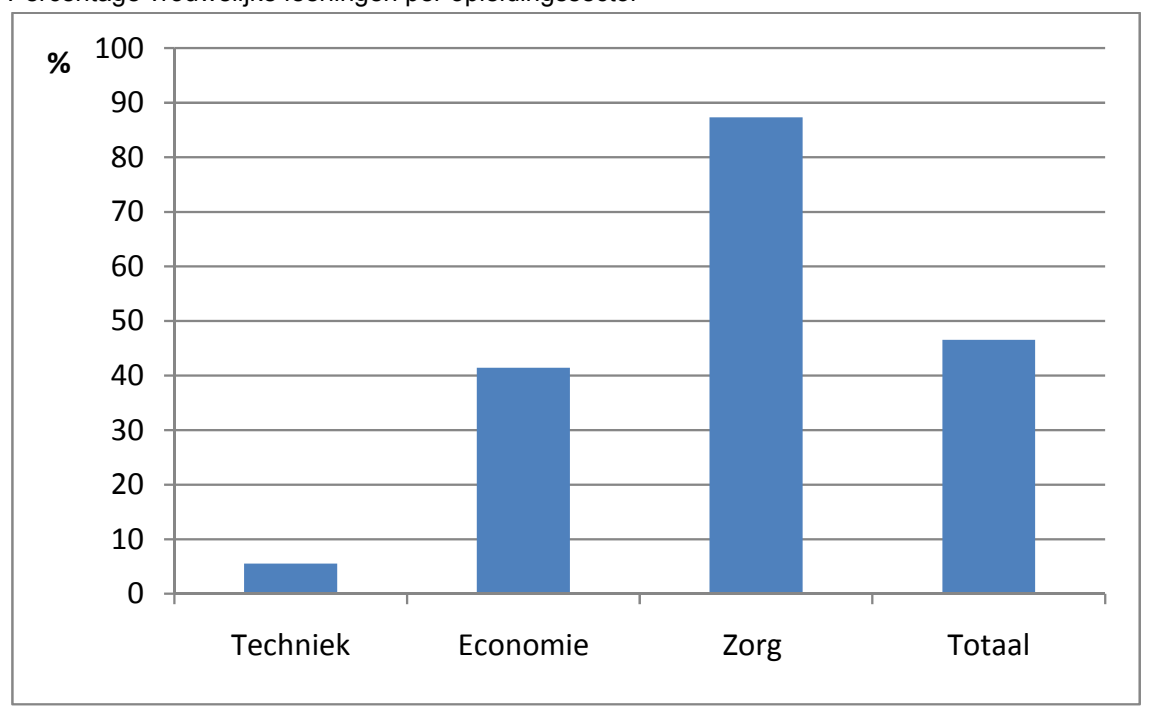

Figuur 3.3 laat voor elk van de drie opleidingssectoren de gemiddelde afstand zien die mannen en vrouwen afleggen tussen de woon- en opleidingslocatie. De relatief kleine groep vrouwen $(\mathrm{N}=260)$ die voor techniek gekozen heeft, is duidelijk bereid de grootste afstand af te leggen naar hun opleidingslocatie (31,5 kilometer). Uit een nadere analyse blijkt dat vrouwen bereid zijn verder te reizen, omdat zij kiezen voor specifieke opleidingsrichtingen binnen de sector techniek (mode, laboratoriumonderwijs en design, art \& technology). Het grootste deel van de vrouwelijke techniekleerlingen kiest voor een opleiding in de mode (bijv. confectie of naaien) en deze worden slechts op één locatie aangeboden. Door hun grote intrinsieke motivatie zijn zij bereid ver (gemiddeld $47,2 \mathrm{~km}$ ) te reizen om de studie die hun voorkeur geniet te kunnen volgen. Dit is in lijn met de bevindingen omtrent de grotere intrinsieke motivatie van techniekleerlingen van Cörvers et al. (2005). Hetzelfde geldt voor vrouwelijke leerlingen die kiezen voor de richting design, art \& technology. Ook zij zijn bereid een relatief grote afstand af te leggen (gemiddeld $31,0 \mathrm{~km}$ ). Vrouwen die daarentegen kiezen voor een zorgopleiding reizen gemiddeld 17,1 kilometer en reizen daarmee het kortst. In tegenstelling tot bij de vrouwelijke leerlingen is er bij de mannelijke leerlingen geen sector die er duidelijk uitspringt qua reisafstand. Wat betreft de sekseverschillen per sector kunnen we twee conclusies trekken. Ten eerste is techniek de enige sector waarvoor geldt dat vrouwen een grotere afstand naar hun opleidingslocatie afleggen dan mannen. Daarnaast is het verschil in de gemiddelde afstand tussen mannen en vrouwen in deze sector ook nog eens het grootst van alle drie de sectoren (11,8 kilometer). 
Figuur 3.3

Gemiddelde afstand tussen woon- en opleidingslocatie leerlingen naar geslacht en opleidingssector

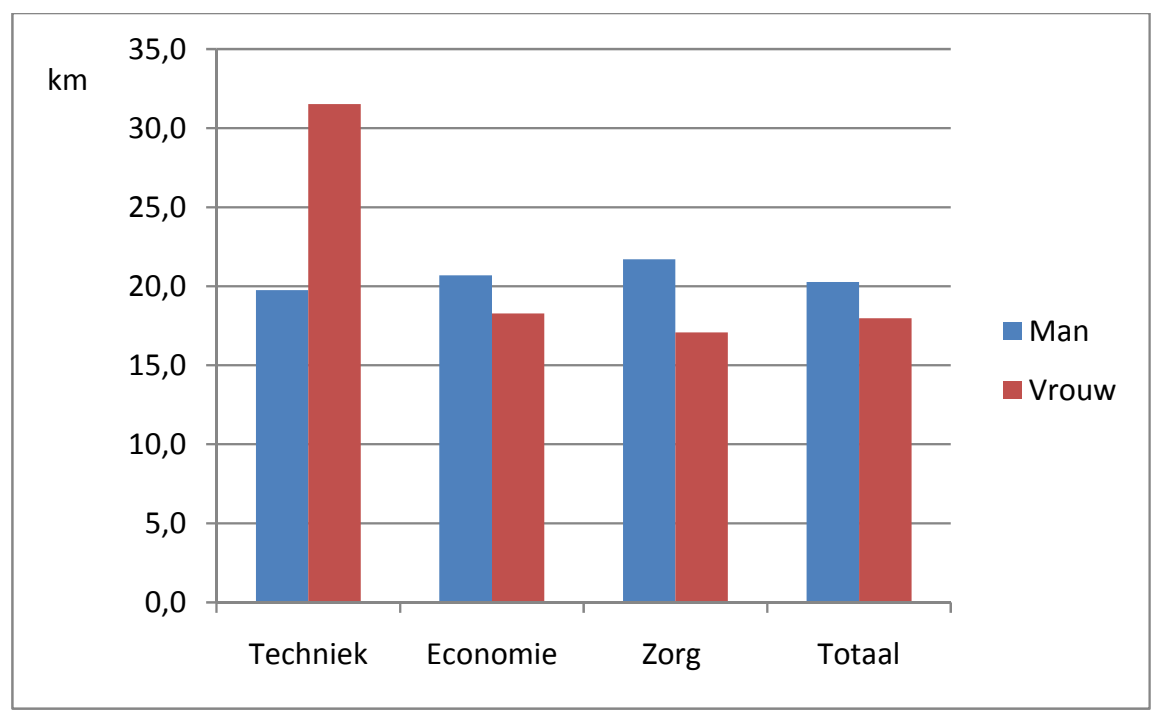

Een andere belangrijk achtergrondkenmerk van deze leerlingen is de herkomst. Veruit het grootste deel van de eerstejaars mbo-leerlingen is autochtoon. Toch zijn er ook ruim 1.550 allochtone leerlingen in het databestand, wat overeenkomt met 9,9\% van het totale bestand. Uit tabel 3.1 blijkt dat autochtonen vaker dan allochtonen kiezen voor een opleidingslocatie die verder van hun woonadres gelegen is. Gemiddeld genomen reist een autochtone leerling (19,6 kilometer) 3,9 kilometer verder naar school dan een allochtone leerling (15,7 kilometer).

Figuur 3.4 geeft voor de drie afzonderlijke opleidingssectoren het percentage allochtonen weer. Er zijn relatief veel allochtone leerlingen die een economische opleiding volgen. Van alle leerlingen die een economische mboopleiding volgen is $16 \%$ allochtoon, terwijl dit percentage voor het totale bestand iets minder dan $10 \%$ bedraagt.

Figuur 3.4

Percentage allochtone leerlingen per opleidingssector

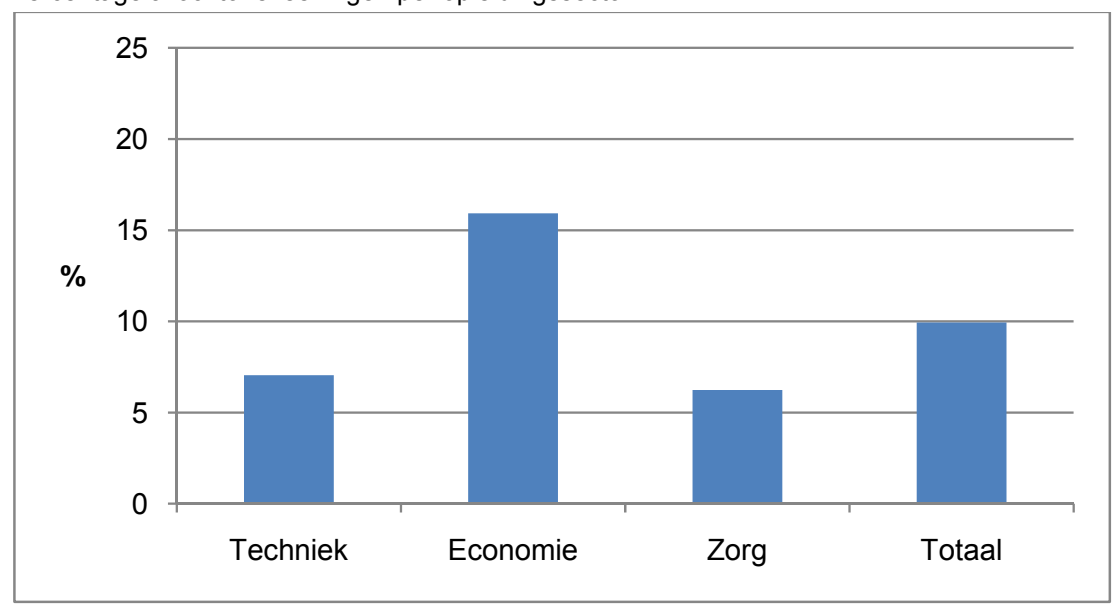

In figuur 3.5 wordt nogmaals de gemiddelde afstand vergeleken die autochtone en allochtone leerlingen afleggen naar hun opleidingslocatie, maar ditmaal wordt er tevens onderscheid gemaakt naar opleidingssector. Autochtone leerlingen uit de sectoren economie en techniek leggen de grootste afstand af naar hun 
opleidingslocatie. Uit deze figuur blijkt duidelijk dat, van alle allochtone leerlingen, degenen met een technische opleiding het verst reizen. De verschillen naar herkomst zijn het grootst onder economieleerlingen. Een autochtoon die een economische opleiding doet legt gemiddeld 5,6 kilometer verder af dan een allochtoon die een economische opleiding doet. In de techniek is dit verschil daarentegen het kleinst. Hier reist een autochtoon gemiddeld genomen 1,8 kilometer verder dan een allochtoon.

Figuur 3.5

Gemiddelde afstand tussen woon- en opleidingslocatie leerlingen naar herkomst en opleidingssector

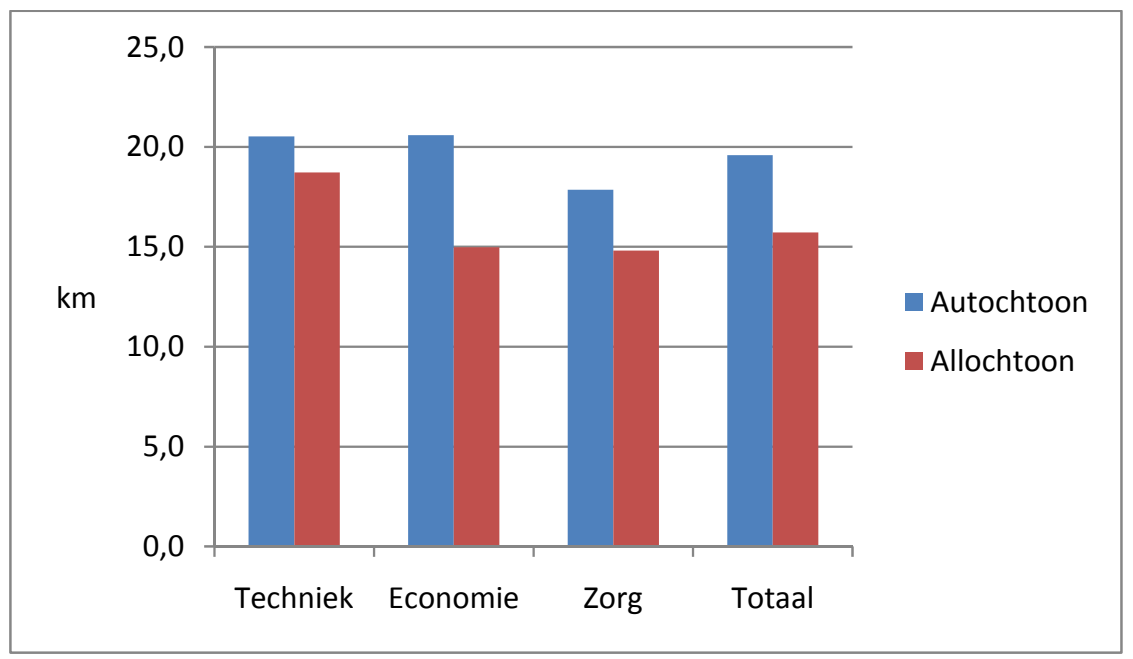

De gemiddelde afstand tussen de woon- en opleidingslocatie kan ook weergegeven worden op basis van zowel geslacht als herkomst, wat resulteert in de vier groepen: mannelijke autochtonen, vrouwelijke autochtonen, mannelijke allochtonen en vrouwelijke allochtonen. Zoals blijkt uit tabel 3.1 pendelen mannelijke autochtone mboleerlingen het verst (20,6 kilometer). Dit in tegenstelling tot vrouwelijke allochtonen die, van alle vier genoemde groepen, doorgaans kiezen voor de kortst bij huis gelegen opleiding (14,4 kilometer). Daarnaast kan geconcludeerd worden dat de opleidingslocatie van mannelijke autochtonen gemiddeld 3,7 kilometer verder van hun woonlocatie gelegen is dan van mannelijke allochtonen. Vrouwelijke autochtonen leggen 4 kilometer verder af naar hun opleidingslocatie dan vrouwelijke allochtonen. Tot slot dient nog opgemerkt te worden dat vrouwelijke autochtonen vaker kiezen voor een verder weg gelegen opleiding dan mannelijke allochtonen.

Tevens is de totale groep mbo-leerlingen gedifferentieerd naar de leerweg die zij volgen. De overgrote meerderheid, 7 op de 10 leerlingen, heeft gekozen voor de beroepsopleidende leerweg (bol). Leerlingen die kiezen voor de beroepsbegeleidende leerweg (bbl) blijken met gemiddeld 25,5 kilometer een aanzienlijk grotere afstand af te leggen dan leerlingen die kiezen voor de bol (16,8 kilometer). Dit is ook logisch aangezien iemand die slechts één dag per week naar school hoeft (bbl), er doorgaans minder moeite mee zal hebben om een grotere afstand naar school af te leggen dan iemand die meerdere dagen per week naar school moet (bol). Dit lijkt een plausibele verklaring voor het feit dat een bbl-leerling kiest voor een opleidingslocatie die gemiddeld bijna 9 kilometer verder gelegen is dan een bol-leerling.

Daarnaast is de gemiddelde afstand tussen woon- en opleidingslocatie van leerlingen gedifferentieerd naar mboniveau. Leerlingen die een opleiding op mbo-niveau 1 volgen, leggen in het algemeen de grootste afstand af (31,5 kilometer). Er zijn op dit niveau echter verhoudingsgewijs veel bbl-leerlingen die doorgaans bereid zijn om verder te reizen, zoals eerder al naar voren kwam. De gemiddelde afstand tussen woon- en opleidingslocatie voor de overige mbo-niveaus verschilt niet veel van elkaar. 
Wat betreft de keuze voor een opleidingssector is het van belang om te bekijken hoe deze afhangt van de genoten vooropleiding. Figuur 3.6 laat zien voor welke sector leerlingen kiezen na een vooropleiding algemeen, techniek, economie, zorg of groen. Leerlingen die techniek als vooropleiding hadden, blijven doorgaans bij hun eerdere keuze en kiezen ook voor een mbo-opleiding in de techniek $(80,1 \%)$. Ook het gros van de leerlingen dat een economische vooropleiding dan wel een opleiding in de zorg heeft gevolgd, kiest ook voor respectievelijk een economie- $(75,3 \%)$ en zorgopleiding $(78,3 \%)$. Voor leerlingen van wie de vooropleiding algemeen of groen was, is het moeilijker om te voorspellen voor welke opleidingssector zij zullen kiezen. ${ }^{7}$

Figuur 3.6

Keuze van mbo-leerlingen voor techniek, economie of zorg naar vooropleiding

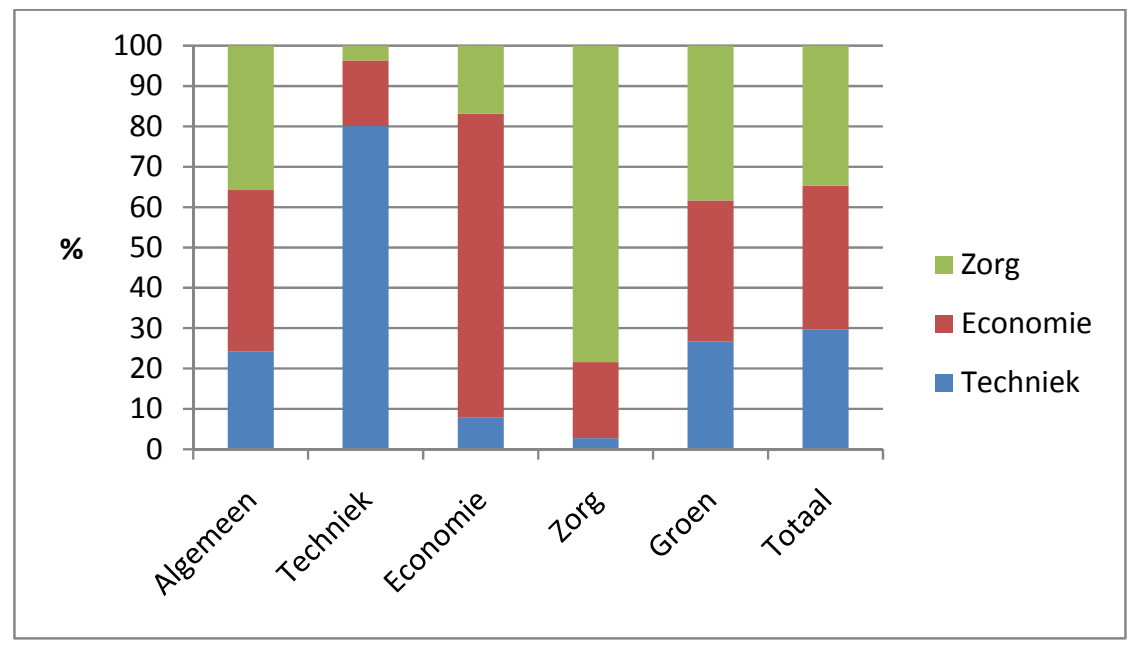

Leerlingen met een algemene vooropleiding (bijv. vmbo theorie of havo) leggen doorgaans de grootste afstand tussen woon- en opleidingslocatie af. Deze leerlingen reizen gemiddeld 21,2 kilometer naar hun opleidingslocatie. Leerlingen van wie de vooropleiding tot de economische sector gerekend wordt, leggen gemiddeld de kortste afstand af (15,4 kilometer). Een leerling met een technische vooropleiding legt gemiddeld 18,4 kilometer af.

\subsection{Verdeling leerlingen over de alternatieve opleidingslocaties}

De vijf ROC's hebben in totaal 31 verschillende opleidingslocaties in het onderzoeksgebied. De vraag is nu voor welke locatie eerstejaars mbo-leerlingen kiezen als we alle locaties rangschikken, variërend van 1 (leerling kiest voor de dichtstbijzijnde opleidingslocatie) tot en met 31 (leerling kiest voor de meest verafgelegen opleidingslocatie). De resultaten op basis van deze rangschikking worden weergegeven in figuur 3.7. Uit deze figuur kan geconcludeerd worden dat bijna een kwart (ruim 23 procent) van de eerstejaars mbo-leerlingen kiest voor de dichtst bij huis gelegen opleidingslocatie. Driekwart van alle leerlingen kiest voor één van de vijf dichtstbijzijnde opleidingslocaties en negen op de tien leerlingen kiest voor één van de tien dichtstbijzijnde opleidingslocaties. Er is sprake van een duidelijk dalende trend. Leerlingen kiezen dus eerder voor een korter bij huis gelegen opleidingslocatie dan voor een verderaf gelegen locatie.

7. Een aanzienlijk deel van de leerlingen met een vooropleiding 'groen' gaat in de praktijk naar een Agrarisch Opleidingscentrum (AOC). Zoals eerder vermeld worden deze echter buiten beschouwing gelaten in dit rapport. 
Figuur 3.7

Verdeling van leerlingen naar nabijheid van de opleidingslocatie, van dichtstbijzijnd $=1 \mathrm{t} / \mathrm{m}$ meest verafgelegen opleidingslocatie $=31$

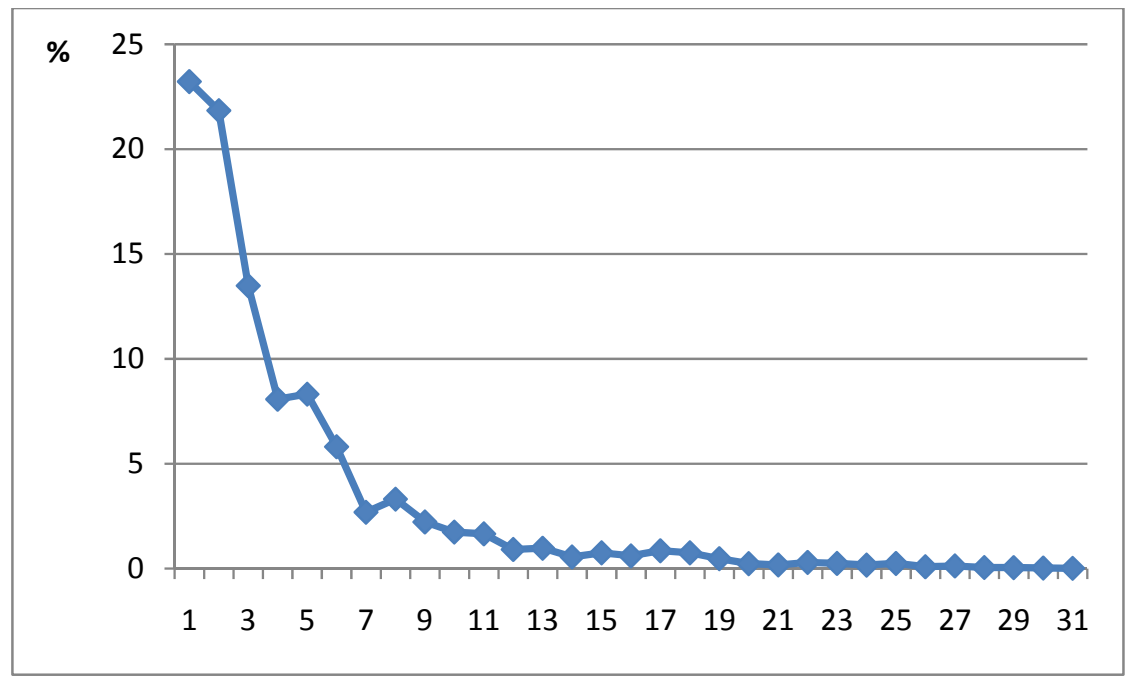

Vervolgens zijn in figuur 3.8 op de horizontale as de 31 opleidingslocaties opnieuw gerangschikt van 1 (dichtstbijzijnd) tot en met 31 (meest verafgelegen). Ditmaal wordt de totale groep leerlingen echter opgesplitst per sector. Het is opvallend dat techniekleerlingen, in tegenstelling tot leerlingen uit de sectoren economie en zorg, het vaakst kiezen voor de op één na dichtstbijzijnde opleidingslocatie. Een mogelijke verklaring hiervoor is dat zij wellicht een grotere bereidheid hebben om verder te reizen door hun grote intrinsieke motivatie. Hierdoor nemen zij de reisafstand eerder voor lief. Ook is het mogelijk dat op de dichtstbijzijnde locatie niet de specifieke techniekopleiding aangeboden wordt die zij graag willen volgen. In het algemeen is er echter evenals in figuur 3.7 een duidelijk dalende trend zichtbaar voor alle drie de sectoren.

Figuur 3.8

Verdeling van leerlingen naar nabijheid van de opleidingslocatie per opleidingssector, van dichtstbijzijnd $=1 \mathrm{t} / \mathrm{m}$ meest verafgelegen opleidingslocatie $=31$

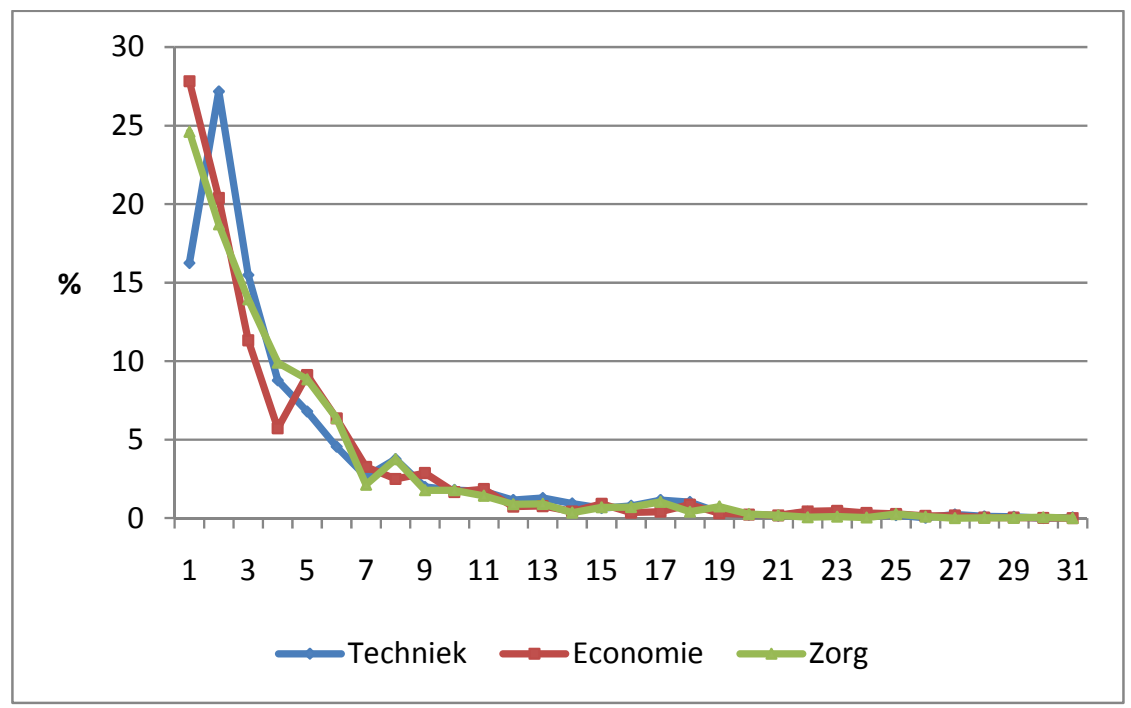


Vervolgens zijn per sector alle opleidingslocaties gerangschikt, variërend van dichtst bij huis gelegen tot meest verafgelegen locatie. Ditmaal is er in de rangschikking dus ook rekening mee gehouden of een sector op een opleidingslocatie wordt aangeboden. Zo wordt duidelijk hoeveel procent van de leerlingen kiest voor de dichtstbijzijnde tot en met de meest verafgelegen opleidingslocatie per opleidingssector. Zo bepalen we bijvoorbeeld het aandeel techniekleerlingen dat kiest voor de dichtstbijzijnde technieklocatie (1), het aandeel techniekleerlingen dat kiest voor de op één na dichtstbijzijnde technieklocatie (2) tot en met het aandeel techniekleerlingen dat kiest voor de meest verafgelegen technieklocatie (19). ${ }^{8}$ Een zelfde indeling is gemaakt voor de economieleerlingen die elk kiezen voor één van de zeventien opleidingslocaties waar economieopleidingen aangeboden worden en voor de zorgleerlingen die elk kiezen voor één van de vijftien opleidingslocaties waar zorgopleidingen aangeboden worden. De resultaten worden weergegeven in figuur 3.9.

Het verschil met de figuren 3.7 en 3.8 zullen we illustreren aan de hand van een voorbeeld. Stel dat een leerling kiest voor een studie techniek bij opleidingslocatie De Muntelaar. En stel dat De Muntelaar voor deze leerling de op één na dichtst bij huis gelegen opleidingslocatie is (rangorde 2 in figuur 3.7 en 3.8). Om de rangorde van de gekozen opleidingslocatie in figuur 3.9 te kunnen bepalen, moeten we echter ook kijken of er techniek op de opleidingslocaties aangeboden wordt. Als er op de dichtstbijzijnde locatie (1) slechts economie en/of zorg aangeboden wordt, is locatie 2 (De Muntelaar) voor deze leerling dus de dichtstbijzijnde technieklocatie (rangorde 1 in figuur 3.9). Figuur 3.9 laat zien dat van alle leerlingen die een technische opleiding volgen, 35\% kiest voor de dichtstbijzijnde technieklocatie. Van alle leerlingen die een zorgopleiding volgen, kiest een nog groter deel voor de dichtstbijzijnde zorglocatie $(45,1 \%)$. Van de leerlingen die een economische opleiding volgen, kiest ten slotte $40,4 \%$ voor de dichtstbijzijnde economielocatie.

Figuur 3.9

Verdeling van leerlingen naar nabijheid van de techniek-, economie- of zorglocatie, van dichtstbijzijnd $=1 \mathrm{t} / \mathrm{m}$ meest verafgelegen opleidingslocatie $=31$

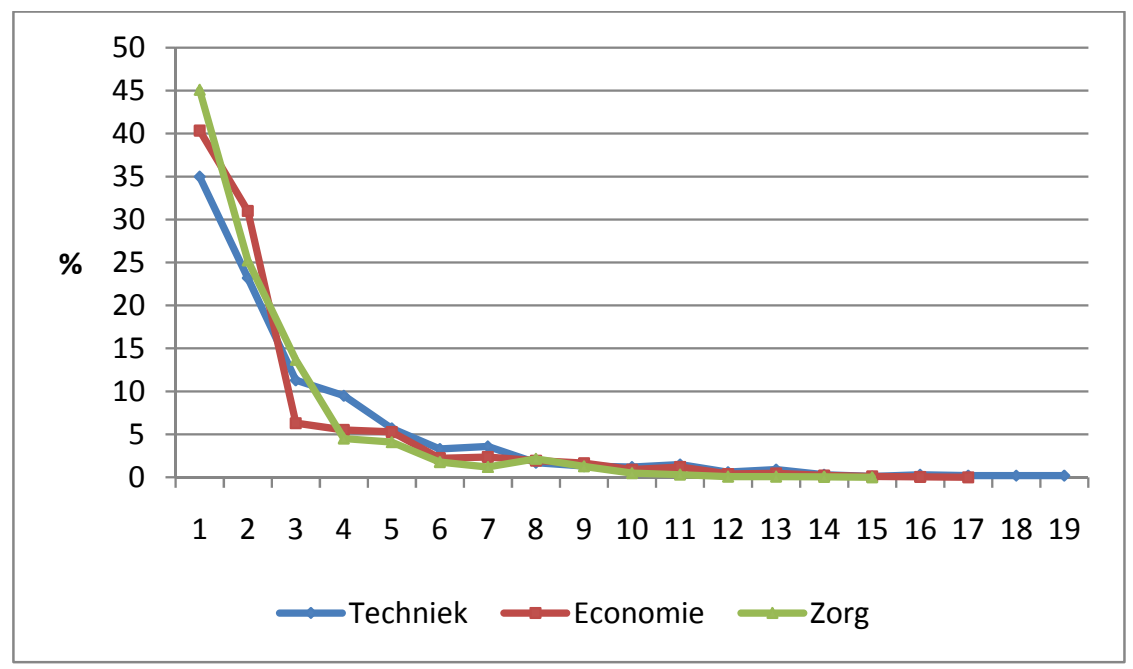

\section{Empirische analyse}

Een grotere afstand tot een opleidingslocatie kan dus een afschrikkende werking hebben op leerlingen om te kiezen voor de opleidingen die worden aangeboden op de betreffende locatie. Leerlingen die kiezen voor een

8. Aangezien er in totaal op 19 van de 31 locaties techniek wordt aangeboden, kan een techniekleerling in deze laatste rangschikking dus maar uit 19 locaties kiezen. 
opleiding kunnen ofwel heen en weer pendelen tussen woon- en opleidingslocatie, ofwel besluiten zich te vestigen in de nabijheid van de betreffende opleidingslocatie. Dit maakt het analyseren van de vraagstelling uiteraard niet eenvoudiger. Uit hoofdstuk 3 bleek echter al dat het voordeel van de analyse in dit rapport is, dat de onderzoekspopulatie bestaat uit eerstejaars mbo-leerlingen voor wie het vaak gaat om de pendel- en niet de verhuisbeslissing. Het betreft voornamelijk leerlingen die van het vmbo of de havo afkomen, en voor wie vaak geldt dat ze nog bij hun ouders wonen. Bovendien heeft ruim 7 op de 10 eerstejaarsleerlingen in de dataset voor bol gekozen en van deze groep is bekend dat de meerderheid nog bij de ouders woont. ${ }^{9}$

Dit hoofdstuk beschrijft de resultaten van de empirische analyses die uitgevoerd zijn om de invloed van afstand op de keuze voor een opleidingslocatie en opleidingssector te onderzoeken. Er zijn drie verschillende afhankelijke variabelen in dit hoofdstuk. In paragraaf 4.1 verklaren we de keuze voor een specifieke opleidingslocatie door middel van een logistische regressieanalyse. Vervolgens gebruiken we in paragraaf 4.2 een multinominaal logistisch regressiemodel dat de keuze tussen opleidingslocaties in verschillende regio's verklaart. Bij de keuze voor een opleidingslocatie is het namelijk van belang of de gewenste sector op de opleidingslocaties wordt aangeboden die voor een leerling in aanmerking komen. In paragraaf 4.3 wordt de keuze voor één van de drie sectoren techniek, economie of zorg verklaard. Ook in paragraaf 4.3 wordt gebruik gemaakt van multinominale logistische regressieanalyse. In paragraaf 4.4 presenteren we de afstandsgevoeligheid van leerlingen aan de hand van marginale effecten. Zo wordt de interpreteerbaarheid van de resultaten duidelijker. In paragraaf 4.5 worden deze marginale effecten gedifferentieerd naar geslacht en etniciteit.

De regressies in dit hoofdstuk hebben als doel om de invloed van reisafstand op de keuze voor een opleidingslocatie en de keuze voor een sector (techniek, economie, of zorg) te schatten. Bij deze verklarende analyses worden uitsluitend exogene variabelen gebruikt als onafhankelijke variabelen. Dat betekent dat als verklarende variabelen alleen de kenmerken aan de rechterkant van de regressievergelijking zijn opgenomen die vaststonden voordat de keuze voor een locatie of mbo-opleiding gemaakt werd. Dit zijn de variabelen geslacht, herkomst, leeftijd, diploma vooropleiding en richting vooropleiding. Keuzevariabelen die simultaan met de keuze voor een locatie en een sector door de leerling bepaald werden, zoals leerweg of mbo-niveau (zie hoofdstuk 3 ), zijn niet opgenomen als exogene variabelen.

\subsection{Keuze voor een opleidingslocatie}

De ruim 15.600 leerlingen in dit onderzoek kunnen ieder kiezen uit 31 verschillende opleidingslocaties in Zuidoost-Nederland. We schatten de kans dat een leerling kiest voor één van deze opleidingslocaties door middel van binominale logistische regressie. Aangezien er in dit onderzoek 31 afzonderlijke opleidingslocaties zijn, schatten we 31 maal de kans dat een leerling kiest voor een bepaalde opleidingslocatie ten opzichte van de kans dat hij kiest voor één van de 30 alternatieve opleidingslocaties. De focus ligt hierbij op de afstandsgevoeligheid die mogelijk een rol speelt in dit keuzeproces. De eerste belangrijke vraag is dan ook; in welke mate laat een leerling zich tijdens het keuzeproces voor een specifieke opleidingslocatie beïnvloeden door de reisafstand?

In de logistische regressie gebruiken we zowel een variabele die de invloed weergeeft van de lineaire afstand (in kilometers) tussen de woning en de opleidingslocatie, alsook een variabele voor het kwadraat van deze lineaire afstand. Dit om te achterhalen of er mogelijk sprake is van een niet-lineair verband. We maken daarnaast gebruik van meerdere exogene controlevariabelen waarvan het aannemelijk is dat deze het keuzeproces beïnvloeden. Naast genoemde afstandsvariabelen nemen we de volgende controlevariabelen op in het regressiemodel: geslacht, herkomst, leeftijd, leeftijd kwadraat, diploma vooropleiding en richting vooropleiding. ${ }^{10}$ Tot slot nemen

9. Om de assumpties te testen zijn gevoeligheidsanalyses uitgevoerd waarbij oudere leerlingen alsook bbl-leerlingen (die vaker op zichzelf wonen) niet meegenomen zijn in de analyses. De resultaten kwamen redelijk overeen.

10. Ook het inkomen van de ouders kan van invloed kan zijn op de keuze om al dan niet naar een verder weg gelegen school te reizen. Data over het inkomen van de ouders van de leerlingen zijn niet beschikbaar. Wel is het gemiddelde inkomen 
we in de regressie ook enkele interacties op: afstand ${ }^{*}$ geslacht, afstand*herkomst, afstand kwadraat*geslacht en afstand kwadraat*herkomst. Deze interacties worden gebruikt om te achterhalen of geslacht en herkomst in combinatie met afstand een afwijkend effect hebben op de keuze voor een opleidingslocatie voor de nietreferentiegroepen (i.e. vrouwen en allochtonen).

De resultaten van de empirische analyse worden hier beschreven aan de hand van een voorbeeld. Dit voorbeeld betreft de kans dat een leerling kiest voor de opleidingslocatie met het grootste aantal leerlingen, opleidingslocatie 18 'De Muntelaar' in Veghel. Tabel 4.1 geeft de resultaten weer van de binominale logistische regressie voor deze locatie. De coëfficiënt B geeft de invloed weer van de betreffende exogene variabele, bijvoorbeeld afstand in kilometers, herkomst of geslacht, op de logaritme van de kans dat de leerling kiest voor opleidingslocatie $18(P)$ versus de kans dat hij/zij voor een andere opleidingslocatie kiest $(1-P)$. De $\log (P /(1-P))$ staat bekend als de zogenaamde 'log odds'. Daaruit volgt dat $\operatorname{Exp}(B)$ de invloed weergeeft op $P /(1-P)$, en dat bijvoorbeeld vrouwen 2,795 maal zoveel kans dan mannen hebben om op locatie 18 in plaats van één van de andere 30 locaties terecht te komen.

Tabel 4.1

Logistische regressie voor de kans dat een leerling kiest voor opleidingslocatie 18 'De Muntelaar' in Veghel

\begin{tabular}{|c|c|c|c|}
\hline & B & & $\operatorname{Exp}(B)$ \\
\hline Constante & $-5,124$ & $* * *$ & 0,006 \\
\hline Afstand & $-0,172$ & $* * *$ & 0,842 \\
\hline Afstand $^{2}$ & 0,001 & $* * *$ & 1,001 \\
\hline Afstand ${ }^{*}$ vrouw & $-0,038$ & $* * *$ & 0,963 \\
\hline Afstand ${ }^{2 *}$ vrouw & 0,000 & $* * *$ & 1,000 \\
\hline Afstand*herkomst & $-0,026$ & & 0,974 \\
\hline Afstand ${ }^{2 *}$ herkomst & 0,000 & * & 1,000 \\
\hline Vrouw & 1,028 & $* * *$ & 2,795 \\
\hline Allochtoon & $-0,645$ & $* *$ & 0,525 \\
\hline Leeftijd & 0,442 & $* * *$ & 1,557 \\
\hline Leeftijd $^{2}$ & $-0,005$ & $* * *$ & 0,995 \\
\hline Geen diploma vooropleiding & 0,726 & $* * *$ & 2,066 \\
\hline \multicolumn{4}{|l|}{ Richting vooropleiding } \\
\hline Algemeen (ref.) & - & & - \\
\hline Techniek & 0,372 & $* * *$ & 1,451 \\
\hline Economie & 0,191 & * & 1,210 \\
\hline Zorg & 0,791 & $* * *$ & 2,205 \\
\hline Groen & $-0,306$ & & 0,736 \\
\hline
\end{tabular}

Significant: ${ }^{* * *} ; p<0,01,{ }^{* *} ; p<0,05,{ }^{*} ; p<0,1, N=15.342$

De afstandsvariabele geeft het effect weer van de afstand die een leerling af moet leggen van zijn woonadres tot opleidingslocatie 18. Zoals blijkt uit tabel 4.1 is er sprake van een significant negatieve invloed van afstand op de keuze voor De Muntelaar. Dit betekent dat bij toenemende afstand tot locatie De Muntelaar, de kans afneemt dat een leerling voor de betreffende opleidingslocatie kiest. De andere opleidingslocaties worden daardoor relatief aantrekkelijker. Het teken van de B-coëfficiënt voor afstand kwadraat is positief en significant, hetgeen betekent dat de invloed van afstand niet-lineair is. Verder blijkt uit tabel 4.1 dat vrouwen significant vaker dan mannen

van postcodegebieden in de gevoeligheidsanalyse meegenomen. Hier kwamen echter geen significante verschillen uit naar voren. 
kiezen voor deze opleidingslocatie. Dit zou er bijvoorbeeld op kunnen duiden dat er relatief veel zorgopleidingen op deze locatie worden aangeboden, omdat vrouwen vaker voor zorg kiezen. De interactieterm tussen geslacht en de lineaire afstandsvariabele is significant negatief, wat wil zeggen dat vrouwen zich nog meer dan mannen laten afschrikken door afstand bij hun keuze voor deze opleidingslocatie. Het gaat echter niet om een lineair effect, zoals kan worden afgeleid uit de positieve coëfficiënt van de interactieterm afstand kwadraat*vrouw.

Allochtonen kiezen significant minder vaak voor opleidingslocatie 18 dan autochtonen $(B=-0,645)$. Allochtonen laten zich echter niet significant meer afschrikken door afstand dan autochtonen. Daarnaast is de invloed van leeftijd op de keuze voor De Muntelaar significant positief $(B=0,442)$, wat betekent dat oudere leerlingen vaker voor deze locatie kiezen. De invloed van leeftijd is niet-lineair, zoals blijkt uit de significante invloed van afstand ${ }^{2}$. Leerlingen die hun vooropleiding zonder diploma verlaten hebben, kiezen relatief vaak voor opleidingslocatie 18 $(B=0,726)$. Verder kan geconcludeerd worden dat leerlingen met een vooropleiding techniek, economie en met name zorg significant vaker voor deze opleidingslocatie kiezen dan leerlingen met een algemene vooropleiding.

Tabel 4.2

Totale effect van afstand op keuze opleidingslocatie

\begin{tabular}{|c|c|c|c|c|c|}
\hline $\begin{array}{r}\text { Opleidings- } \\
\text { locatie }\end{array}$ & $5 \mathrm{~km}$ & 10 km & 20 km & $50 \mathrm{~km}$ & $100 \mathrm{~km}$ \\
\hline 1 & n.s. & & & & \\
\hline 2 & $-0,348$ & $-0,695$ & $-1,390$ & $-3,475$ & $-6,950$ \\
\hline 3 & n.s. & & & & \\
\hline 4 & $-1,142$ & $-2,251$ & $-4,368$ & $-9,915$ & $-16,480$ \\
\hline 5 & $-1,089$ & $-2,136$ & $-4,106$ & $-9,020$ & $-13,890$ \\
\hline 6 & $-0,478$ & $-0,939$ & $-1,812$ & $-4,035$ & $-6,420$ \\
\hline 7 & n.s. & & & & \\
\hline 8 & $-0,154$ & $-0,354$ & $-0,894$ & $-3,630$ & $-11,910$ \\
\hline 9 & $-0,674$ & $-1,348$ & $-2,696$ & $-6,740$ & $-13,480$ \\
\hline 10 & n.s. & & & & \\
\hline 11 & $-0,669$ & $-1,337$ & $-2,674$ & $-6,685$ & $-13,370$ \\
\hline 12 & $-0,195$ & $-0,405$ & $-0,872$ & $-2,645$ & $-6,840$ \\
\hline 13 & $-0,137$ & $-0,266$ & $-0,500$ & $-1,010$ & $-1,220$ \\
\hline 14 & $-0,816$ & $-1,599$ & $-3,068$ & $-6,695$ & $-10,140$ \\
\hline 15 & n.s. & & & & \\
\hline 16 & $-0,496$ & $-0,975$ & $-1,884$ & $-4,215$ & $-6,780$ \\
\hline 17 & n.s. & & & & \\
\hline 18 & $-0,834$ & $-1,617$ & $-3,030$ & $-6,045$ & $-6,990$ \\
\hline 19 & $-0,452$ & $-0,903$ & $-1,806$ & $-4,515$ & $-9,030$ \\
\hline 20 & $-0,484$ & $-0,948$ & $-1,820$ & $-3,980$ & $-6,060$ \\
\hline 21 & $-1,155$ & $-2,279$ & $-4,436$ & $-10,175$ & $-17,300$ \\
\hline 22 & n.s. & & & & \\
\hline 23 & $-0,453$ & $-0,905$ & $-1,810$ & $-4,525$ & $-9,050$ \\
\hline 24 & n.s. & & & & \\
\hline 25 & $-0,347$ & $-0,693$ & $-1,386$ & $-3,465$ & $-6,930$ \\
\hline 26 & $-0,378$ & $-0,739$ & $-1,414$ & $-3,055$ & $-4,510$ \\
\hline 27 & n.s. & & & & \\
\hline 28 & n.s. & & & & \\
\hline 29 & $-0,451$ & $-0,886$ & $-1,708$ & $-3,790$ & $-5,980$ \\
\hline 30 & n.s. & & & & \\
\hline 31 & $-0,511$ & $-1,022$ & $-2,044$ & $-5,110$ & $-10,220$ \\
\hline
\end{tabular}

Op dezelfde wijze schatten we de kans dat een leerling met dezelfde achtergrondkenmerken kiest voor elk van de overige 30 opleidingslocaties. Aangezien we vooral geïnteresseerd zijn in de rol die afstand speelt, presenteren we in tabel 4.2 alleen de invloed van afstand ('afstand' en 'afstand kwadraat') op de keuze voor elk van de 31 locaties. De resultaten worden verkregen door het schatten van 31 afzonderlijke binominale logistische 
regressies, op dezelfde wijze als eerder in tabel 4.1 weergegeven voor opleidingslocatie 18, De Muntelaar. De kolom ' 5 km' geeft weer hoe een leerling die vijf kilometer van een opleidingslocatie vandaan woont, zich bij de locatiekeuze laat beïnvloeden door afstand. Hetzelfde wordt weergegeven voor een leerling met dezelfde achtergrondkenmerken die respectievelijk 10, 20, 50 en 100 kilometer van de opleidingslocatie vandaan woont. In de tabel wordt alleen de invloed van de afstanden gepresenteerd die de keuze voor een opleidingslocatie statistisch significant beïnvloeden.

Aan de hand van een voorbeeld illustreren we hoe de waardes in tabel 4.2 tot stand zijn gekomen. De waarde van de B-coëfficiënt die aangeeft wat de invloed is van een afstand van 5 kilometer op de keuze voor locatie 18 is bijvoorbeeld -0,834. Deze waarde wordt berekend door de B-coëfficiënt van de lineaire afstand tot locatie 18 te vermenigvuldigen met het aantal kilometers tot locatie $18(-0,172 * 5)$ en hierbij de invloed van afstand kwadraat op te tellen $\left(0,001^{*} 5^{2}\right)$. Zoals verwacht blijkt uit de tabel dat de reisafstand van thuis naar school de keuze voor een opleidingslocatie in negatieve zin beïnvloedt. Naarmate iemand verder van een locatie vandaan woont, zal hij dus minder snel voor deze locatie kiezen. Deze afstandsgevoeligheid is eerder aangeduid als 'distance deterrence'.

\subsection{Keuze tussen verschillende regio's}

Tevens is bekeken wat de invloed is van afstand op de keuze om te gaan studeren in een bepaalde regio ten opzichte van de kans om te gaan studeren in een andere regio. We modeleren deze keuze door middel van multinominale logistische regressie. Aangezien leerlingen in het onderzoeksgebied de keuze hebben uit 31 verschillende opleidingslocaties zouden eigenlijk alle 31 afstanden tussen het woonadres en de verschillende opleidingslocaties als onafhankelijke variabelen in het model opgenomen moeten worden. Het blijkt echter dat de reisafstanden naar meerdere van deze locaties onderling (te) hoog gecorreleerd zijn, wat problemen oplevert aangaande multicollineariteit. Vanuit dit oogpunt is er voor gekozen om de oorspronkelijke 31 onafhankelijke afstandsvariabelen te reduceren door middel van factoranalyse. ${ }^{11}$

Met behulp van factoranalyse wordt de informatie die in eerste instantie wordt weergegeven door een groot aantal variabelen gereduceerd tot een kleiner aantal variabelen, ook wel factoren genoemd. ${ }^{12}$ Op deze manier houden we een gering aantal factoren over die een lineaire combinatie vormen van de originele afstandsvariabelen (Hair, Babin, Money \& Samouel, 2003). Elke afzonderlijke factor is een weergave van de afstanden naar de opleidingslocaties gelegen binnen die regio. De factoren die gebruikt worden in de analyses dienen nagenoeg evenveel van de variantie te verklaren als de oorspronkelijke afstandsvariabelen. ${ }^{13}$

Bij factoranalyse is het van belang te bepalen hoeveel factoren meegenomen worden om de oorspronkelijke variabelen zo goed mogelijk te benaderen. Ook hiervoor zijn weer twee opties volgens Hair et al. (2003). De eerste methode bepaalt het aantal mee te nemen factoren aan de hand van de zogenaamde 'eigenwaarde'. De eigenwaarde is een maat die de variantie van een factor aangeeft. Als voorwaarde om als factor in de analyses meegenomen te worden dient deze een waarde van ten minste 'één' aan te nemen. In dit rapport is de eigenwaarde van de vijfde factor de laatste eigenwaarde die minimaal 'één' bedraagt $(1,595)$. Dit zou betekenen

11. Er is gekozen om afstand in deze analyse in log kilometers uit te drukken, omdat de factorresultaten hiervoor plausibelere resultaten opleverden dan voor lineaire kilometers. Wanneer we de factoranalyse zouden baseren op afstand gemeten in lineaire kilometers zou dit resulteren in 3 grote factorgebieden. De factorgebieden op basis van log afstand zijn dus minder grof.

12. Er worden in het algemeen twee verschillende factormodellen onderscheiden. Voor de factoranalyses in dit rapport maken we gebruik van de 'principale-componentenanalyse'. Volgens Hair et al. (2003) is dit veruit de meest gebruikte methode. Deze vorm van factoranalyse verschilt van de 'common factoranalyse' in het feit dat eerstgenoemde analyse gebruik maakt van de totale variantie van het databestand, terwijl laatstgenoemde slechts gebaseerd is op de 'common variance' (Hair et al., 2003).

13. Vervolgens dient er bij het gebruik van de 'principale-componentenanalyse' een keuze gemaakt te worden over de wijze van factorrotatie. Er zijn twee mogelijkheden voor rotatie: orthogonale rotatie en oblique rotatie (Hair et al., 2003). In dit rapport kiezen we voor orthogonale rotatie, zodat de factoren na rotatie ongecorreleerd en onafhankelijk van elkaar zijn. Deze methode van factorrotatie is volgens Hair et al. (2003) ook veruit de meest gebruikte methode. 
dat er vijf factoren als onafhankelijke variabelen in de analyses meegenomen worden. Deze geven weer hoe afstand de keuze voor een bepaalde regio beïnvloedt.

De tweede methode voor het bepalen van het aantal factoren is door middel van het analyseren van het cumulatieve percentage van de variantie in de originele data dat verklaard wordt door alle factoren samen. Hair et al. (2003) gaan uit van het criterium dat ten minste $60 \%$ van de totale variantie verklaard moet worden door de factoren. In onze analyse bedraagt het cumulatieve percentage verklarende variantie van de vijf factoren $87,6 \%$, hetgeen betekent dat ruimschoots aan dit criterium wordt voldaan.

Naast beide hiervoor genoemde voorwaarden voor het bepalen van het aantal factoren noemen Hair et al. (2003) nog één additionele vereiste en dat is dat ze ook daadwerkelijk theoretische betekenis moeten hebben. De vijf factoren in onze analyses zijn plausibel en voldoen dus aan dit criterium. Zoals blijkt uit figuur 4.1 liggen de opleidingslocaties die behoren tot een factor, geografisch namelijk dicht bij elkaar.

De 31 oorspronkelijke variabelen die de logaritmes weergeven van de afstand tussen de woonlocatie en de 31 verschillende opleidingslocaties kunnen nu dus vervangen worden door vijf factoren. Deze vijf factoren geven voor iedere leerling de logaritme weer van de afstand naar de opleidingslocaties gelegen in de betreffende regio en kunnen nu als onafhankelijke variabelen in de verdere analyses opgenomen worden. De vijf factoren geven de invloed weer van afstand op de keuze om te gaan studeren in een regio. Zo vertegenwoordigt factor 1 voor iedere leerling de afstanden naar opleidingslocaties gelegen in de regio Eindhoven/Helmond, factor 2 de afstanden naar opleidingslocaties gelegen in Venlo, factor 3 de afstanden naar opleidingslocaties gelegen in de regio Oss/Vught/Den Bosch, factor 4 de afstanden naar opleidingslocaties gelegen in de regio Roermond/SittardGeleen/Weert en factor 5 ten slotte de afstanden naar opleidingslocaties gelegen in de regio Cuijk/Uden/Veghel/Venray. 
Regio's van opleidingslocaties op basis van factoranalyse

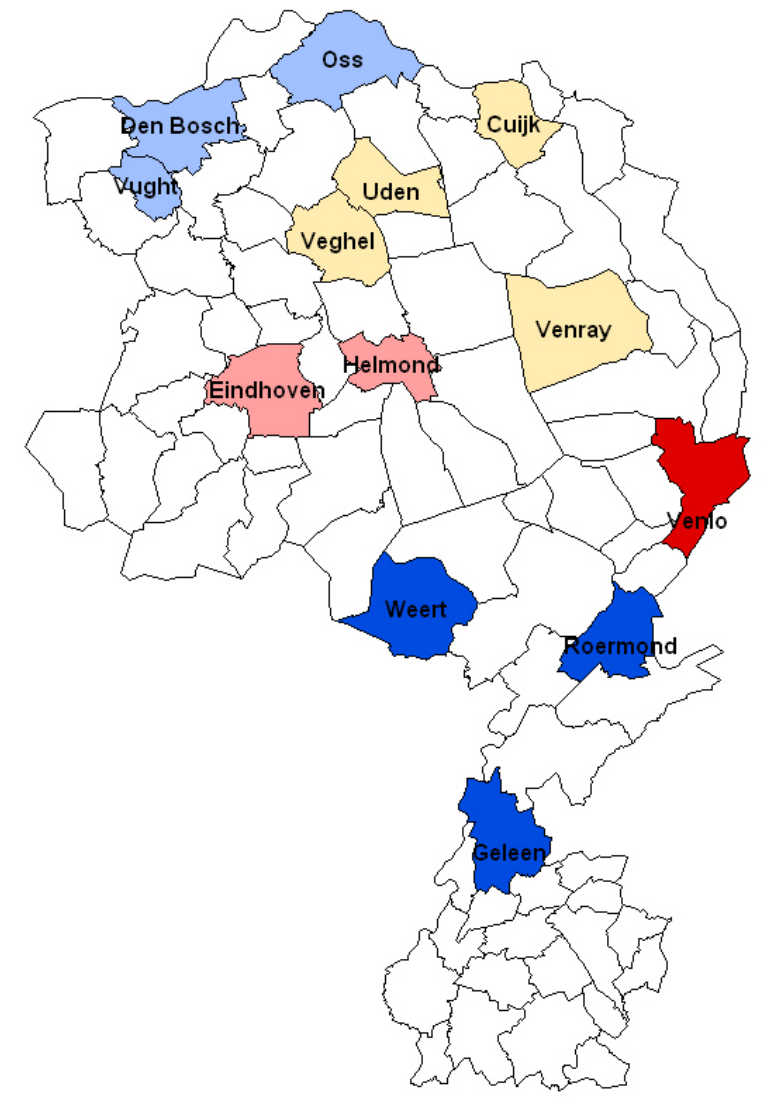

Opmerking: Factor 1 = Eindhoven/Helmond; factor 2 = Venlo; factor 3 = Den Bosch/Oss $/$ Vught; factor $4=$ Roermond/Weert/Sittard-Geleen; factor $5=$ Veghel/Uden/Cuijk/Venray.

De vijf afstandsvariabelen kunnen nu als onafhankelijke variabelen gebruikt worden in het model. Tabel 4.3 geeft de resultaten weer van deze multinominale logistische regressieanalyse. We schatten de kans dat een leerling gaat studeren in een specifieke regio ten opzichte van de kans dat hij gaat studeren in de referentieregio (regio 1: Eindhoven/Helmond).

Uit de eerste kolom van tabel 4.3 blijkt dat de invloed van de afstand naar regio 1 (Eindhoven/Helmond) op de kans dat een leerling gaat studeren in regio 2 (Venlo), significant positief is $(B=1,802)$. Wanneer de afstand naar opleidingslocaties in de regio Eindhoven/Helmond dus toeneemt, zal de kans dat een leerling kiest voor Venlo significant toenemen (ten opzichte van de kans dat deze kiest voor Eindhoven/ Helmond). Het omgekeerde is het geval als de afstand naar Venlo toeneemt. Uit dezelfde kolom blijkt namelijk dat de kans dat een leerling kiest voor Venlo significant afneemt naarmate de afstand ten opzichte van Venlo groter wordt $(B=-1,826)$. 
Tabel 4.3

Multinominale logistische regressie voor de kans dat een leerling kiest voor een opleidingslocatie in een regio

\begin{tabular}{|c|c|c|c|c|c|c|c|c|}
\hline \multirow[b]{2}{*}{ Constante } & \multicolumn{2}{|c|}{$\begin{array}{c}\text { Regio 2: } \\
\text { Venlo }\end{array}$} & \multicolumn{2}{|c|}{$\begin{array}{l}\text { Regio 3: } \\
\text { Den Bosch/ } \\
\text { Oss/ Vught }\end{array}$} & \multicolumn{2}{|c|}{$\begin{array}{c}\text { Regio 4: } \\
\text { Roermond/ } \\
\text { Weert/ Geleen }\end{array}$} & \multicolumn{2}{|c|}{$\begin{array}{c}\text { Regio 5: } \\
\text { Veghel/ Uden/ } \\
\text { Cuijk/ Venray } \\
\text { B }\end{array}$} \\
\hline & $-1,079$ & & 6,518 & $* * *$ & $-3,800$ & *** & $-3,789$ & $* * *$ \\
\hline \multicolumn{9}{|l|}{ Afstandsvariabelen } \\
\hline Factor 1 & 1,802 & $* * *$ & 2,767 & *** & 1,201 & $* * *$ & 1,158 & $* * *$ \\
\hline Vrouw*factor 1 & 0,302 & & $-0,498$ & $* * *$ & $-0,417$ & ** & 0,032 & \\
\hline Herkomst*factor 1 & $-0,055$ & & $-0,781$ & $* * *$ & $-0,523$ & & 0,045 & \\
\hline Factor 2 & $-1,826$ & *** & 1,295 & $* * *$ & $-0,979$ & $* * *$ & 0,177 & $* *$ \\
\hline Vrouw*factor 2 & 0,081 & & 0,030 & & $-0,197$ & & $-0,497$ & $* * *$ \\
\hline Herkomst*factor 2 & 0,390 & ** & 0,685 & & $-0,084$ & & $-0,067$ & \\
\hline Factor 3 & 1,648 & $* * *$ & $-2,517$ & $* * *$ & 1,442 & *** & $-1,339$ & $* * *$ \\
\hline Vrouw*factor 3 & $-0,926$ & $* * *$ & 0,405 & $* * *$ & 0,481 & & $-0,012$ & \\
\hline Herkomst*factor 3 & 0,155 & & 0,180 & & 0,658 & & 0,146 & \\
\hline Factor 4 & $-1,310$ & $* * *$ & 0,522 & *** & $-1,889$ & *** & 1,340 & $* * *$ \\
\hline Vrouw*factor 4 & $-0,087$ & & 0,018 & & $-0,666$ & $* * *$ & $-0,167$ & \\
\hline Herkomst*factor 4 & 0,138 & & $-0,130$ & & $-0,097$ & & 0,361 & \\
\hline Factor 5 & $-0,400$ & $* * *$ & $-0,539$ & *** & 0,732 & $* * *$ & $-1,461$ & $* * *$ \\
\hline Vrouw*factor 5 & $-0,128$ & & $-0,084$ & & 0,681 & $* * *$ & $-0,193$ & ** \\
\hline Herkomst*factor 5 & 0,292 & & 0,198 & & 0,950 & ** & $-0,186$ & \\
\hline Vrouw & 0,869 & *** & 0,135 & & $-0,989$ & ** & 0,052 & \\
\hline Allochtoon & 0,110 & & $-0,564$ & & $-1,296$ & & $-1,267$ & $* * *$ \\
\hline Leeftijd & $-0,131$ & ** & $-0,539$ & $* * *$ & 0,102 & ** & 0,190 & $* * *$ \\
\hline Leeftijd $^{2}$ & 0,001 & & 0,007 & $* * *$ & $-0,002$ & $* * *$ & $-0,002$ & $* * *$ \\
\hline Geen diploma vooropleiding & $-0,456$ & *** & $-0,258$ & ** & 0,165 & & 0,593 & $* * *$ \\
\hline \multicolumn{9}{|l|}{ Richting vooropleiding } \\
\hline \multicolumn{9}{|l|}{ Algemeen (ref.) } \\
\hline Groen & 0,347 & & 0,372 & & 0,968 & $* * *$ & 0,294 & \\
\hline Techniek & 0,390 & *** & 0,196 & & 0,626 & *** & 0,403 & *** \\
\hline Economie & $-0,033$ & & 0,140 & & 0,190 & & 0,746 & *** \\
\hline Zorg & 0,374 & *** & $-0,171$ & & 0,567 & *** & 0,934 & *** \\
\hline
\end{tabular}

Significant: ${ }^{* *} ; p<0,01,{ }^{* *} ; p<0,05,{ }^{*} ; p<0,1 ; N=15.342$

Opmerkingen:

- Bij de afhankelijke variabele is regio 1 (Eindhoven/Helmond) de referentieregio.

- De factoren hebben betrekking op de afstand tot de regio met hetzelfde nummer.

- Factor 1 = Eindhoven/Helmond, factor 2 = Venlo, factor 3 = Den Bosch/Oss/Vught, factor 4 = Roermond/Weert/SittardGeleen, factor $5=$ Veghel/Uden/Cuijk/Venray.

Ook voor regio 3 (Den Bosch/Oss/Vught) kunnen soortgelijke conclusies getrokken worden met betrekking tot de mate waarin de keuze voor deze regio afhankelijk is van afstand. Uit tabel 4.3 kan geconcludeerd worden dat leerlingen significant vaker kiezen voor een opleidingslocatie in regio 3 als de afstand toeneemt naar de referentieregio $(B=2,767)$. Zoals blijkt uit de negatieve $B$-coëfficiënt van factor 3 , kiest een leerling significant minder vaak voor de regio Den Bosch/Oss/Vught $(B=-2,517)$ als hij verder van deze regio vandaan woont.

Uit de tabel blijkt tevens dat als leerlingen verder van Eindhoven/Helmond wonen, zij relatief eerder kiezen voor regio 4 , te weten Roermond/Weert/Sittard-Geleen $(B=1,201)$. Verder is er zoals verwacht ook sprake van een significant negatief verband tussen de afstand naar Roermond/Weert/ Sittard-Geleen en de keuze voor een opleidingslocatie gelegen in deze regio $(B=-1,889)$. 
De laatste regio die op basis van factoranalyse onderscheiden wordt in dit rapport is regio 5, i.e. Veghel/Uden/Cuijk/Venray. Wanneer de afstand naar de referentieregio toeneemt, gaat een leerling doorgaans eerder studeren in regio Veghel/ Uden/Cuijk/Venray $(B=1,158)$ dan in Eindhoven/Helmond. Neemt de afstand ten opzichte van regio 5 daarentegen toe, dan kiest een leerling eerder voor een opleidingslocatie in de referentieregio dan voor regio $5(B=-1,461)$.

Voor alle regio's blijkt derhalve te gelden dat als de afstand tot de betreffende regio toeneemt, de kans afneemt dat leerlingen in die regio gaan studeren (ten opzichte van de referentieregio Eindhoven/Helmond). Tevens geldt dat als de afstand tot de referentieregio toeneemt, de kans toeneemt dat men in één van de andere regio's gaat studeren. Deze uitkomsten zijn dus conform de verwachting van de hypothese over 'distance deterrence'. Moeilijker te verklaren zijn echter de tekens voor de verbanden tussen niet-referentieregio's, bijvoorbeeld een toenemende reisafstand naar de locaties in regio 3 (Den Bosch/Oss/Vught) vergroot de kans op de keuze voor de locaties in regio 2 (Venlo; $B=1,648$ ), maar een toenemende afstand naar regio 4 (Roermond/Weert/SittardGeleen) verkleint juist de kans dat leerlingen kiezen voor regio 2 (Venlo; B=-1,310).

Interacties geslacht en afstand

De interacties tussen geslacht en factor 1 (Eindhoven/Helmond) geven weer of de invloed van afstand naar regio Eindhoven/Helmond afwijkt voor vrouwen. Zo zien we bijvoorbeeld dat wanneer de afstand naar regio Eindhoven/Helmond toeneemt, de kans dat vrouwen voor regio Den Bosch/Oss/Vught kiezen significant kleiner is dan voor mannen $(B=-0,498)$. Dit betekent dat vrouwen zich in dit geval minder snel laten afschrikken door afstand en dus minder afstandsgevoelig zijn. Ook met betrekking tot de keuze voor regio 4 (Roermond/Weert/ Sittard-Geleen) kan geconcludeerd worden dat de invloed van afstand voor vrouwen significant verschilt van mannen. Is de B-coëfficiënt van mannen voor de afstand naar regio 1 Eindhoven/Helmond 1,201, voor vrouwen is deze B-coëfficiënt $0,784(=1,201-/-0,417)$.

Zoals we eerder zagen kiezen leerlingen significant vaker voor regio 5 (Veghel/Uden/Cuijk/Venray) ten opzichte van de referentieregio als de afstand naar regio 2 (Venlo) toeneemt. Dit geldt echter niet voor vrouwen $(0,177$-/$0,497=-0,320)$.

De interactieterm vrouw*factor 3 is significant van invloed op zowel de keuze voor Venlo als de keuze voor Den Bosch/Oss/Vught. Als de afstand naar regio 3 toeneemt, kiezen vrouwen in mindere mate voor Venlo ten opzichte van de referentieregio (Eindhoven/Helmond). Daarnaast heeft de interactieterm vrouw*factor 3 een significante invloed op de keuze voor regio 3 (Den Bosch/Oss/Vught). Als de afstand naar regio 3 toeneemt, kiezen leerlingen significant minder vaak voor regio $3(B=-2,517)$. De significant positieve B-coëfficiënt voor vrouwen bij toenemende afstand wil zeggen dat zij eerder dan mannen voor regio 3 zullen kiezen als de afstand naar regio 3 toeneemt $(B=0,405)$. Vrouwen zijn in dit geval dus minder afstandsgevoelig.

De interactieterm vrouw*factor 4 is significant negatief voor de keuze om te gaan studeren in regio 4: Roermond/Weert/Sittard-Geleen. Leerlingen laten zich in het algemeen bij toenemende afstand tot regio 4 afschrikken door afstand en kiezen daardoor minder snel voor deze regio in vergelijking met de referentieregio $(B=-1,889)$. Vrouwen kiezen bij toenemende afstand nog minder snel voor regio 4 , zoals blijkt uit de significant negatieve B-coëfficiënt $(-0,666)$. Hier zijn vrouwen dus afstandgevoeliger dan mannen.

Als de afstand naar regio 5 (Veghel/Uden/Cuijk/Venray) toeneemt, kiezen vrouwen nog meer dan mannen voor regio 4 (Roermond/Weert/Sittard-Geleen) vergeleken met regio 1 (Eindhoven/ Helmond). Daarnaast geldt dat als de afstand naar regio 5 toeneemt, vrouwen nog minder snel voor regio 5 kiezen dan mannen doen $(B=-0,193)$. Dit betekent dat het effect van 'distance deterrence' in dit geval groter is voor vrouwen. 
Naast interacties tussen geslacht en afstand worden ook interacties tussen herkomst en afstand in het model opgenomen. Dit stelt ons in staat conclusies te trekken over mogelijke verschillen tussen autochtonen en allochtonen aangaande het effect van afstand op de regio waar ze gaan studeren.

De interactieterm allochtoon*factor 1 heeft een significant negatieve invloed op de kans om te kiezen voor regio 3 (Den Bosch/Oss/Vught). Wanneer de afstand naar regio 1 groter wordt laten allochtonen zich minder snel door afstand beïnvloeden als het gaat om de keuze voor regio $3(B=-0,781)$. Allochtone leerlingen zijn in dit geval dus minder afstandsgevoelig.

Tevens is de interactieterm tussen herkomst en afstand naar Venlo significant van invloed op de keuze voor Venlo. Als de afstand naar Venlo toeneemt, heeft dit dus een andere invloed op het keuzegedrag van allochtonen dan van autochtonen. Hoewel allochtone leerlingen minder vaak voor Venlo kiezen als de afstand naar Venlo toeneemt, laten zij zich minder afschrikken door de reisafstand dan autochtone leerlingen.

Als de afstand naar regio 3 toeneemt, zijn er geen significante verschillen op de keuze voor een regio tussen allochtonen en autochtonen. Ook het effect van de afstand naar regio 4 op de keuze voor een regio verschilt niet significant tussen autochtone en allochtone leerlingen.

Tot slot kan uit tabel 4.3 geconcludeerd worden, dat als de afstand ten opzichte van regio 5 toeneemt, allochtonen significant vaker voor regio 4 kiezen dan autochtonen $(B=0,950)$.

\subsection{Keuze voor een opleidingssector}

De keuze voor een opleidingssector is mede afhankelijk van het opleidingsaanbod op de verschillende locaties in een regio. In dit rapport gaat het om opleidingen in de sectoren techniek, economie en zorg. We modelleren daarom de kans dat een leerling kiest voor een bepaalde sector door middel van multinominale logistische regressie. Ook hier gebruiken we deze statistische methode omdat de afhankelijke variabele in dit model bestaat uit meerdere categorieën. De keuze voor een economische opleiding is hierbij de referentiecategorie. Dit betekent dat we de kans schatten dat een leerling kiest voor een technische opleiding (of zorgopleiding) ten opzichte van de kans dat deze kiest voor economie.

Er worden meerdere modellen gebruikt om de keuze voor een sector te verklaren. Ook in deze modellen ligt de nadruk op de rol die afstand speelt. Afstand wordt hierin gemeten in kilometers. In het eerste model (tabel 4.4) wordt gekeken wat de invloed is van de afstand naar respectievelijk de dichtstbijzijnde techniek-, economie- en zorglocatie op de keuze voor een bepaalde sector. De keuze voor een sector (bijv. techniek) wordt namelijk niet uitsluitend bepaald door de nabijheid van een technieklocatie. Het is namelijk ook mogelijk dat leerlingen die aanvankelijk een voorkeur hadden voor economie of zorg, uiteindelijk toch voor techniek kiezen, omdat de afstand tot een economie- of zorglocatie het voor hen minder aantrekkelijk maakt om voor genoemde sectoren te kiezen. Om die reden wordt de afstand tot de dichtstbijzijnde locatie waar deze alternatieve sectoren aangeboden worden ook in het regressiemodel meegenomen.

Het tweede model (tabel 4.5) is een uitbreiding van het eerste model. In tabel 4.5 worden, naast de variabele voor de afstand tot de dichtstbijzijnde locatie per sector uit tabel 4.4, ook een variabele meegenomen die per sector het verschil in kilometers weergeeft tussen de op één na dichtstbijzijnde en de dichtstbijzijnde locatie, alsook een variabele die per sector het verschil in kilometers weergeeft tussen de op twee na dichtstbijzijnde en de op één na dichtstbijzijnde locatie. Het doel van deze analyse is om na te gaan of behalve de dichtstbijzijnde locatie voor techniek-, economie- en zorgopleidingen ook de iets verder weg gelegen locaties invloed uitoefenen op de keuze voor een sector. Te verwachten valt dat die invloed kleiner zal zijn, omdat de meest afstandsgevoelige leerlingen (i.e. met grote 'distance deterrence') voor de dichtstbijzijnde locaties kiezen. Dit 
effect is dus al meegenomen in de variabele die de afstand tot de dichtstbijzijnde locatie weergeeft. Leerlingen die kiezen voor een iets verder weg gelegen opleidingslocatie hebben waarschijnlijk andere motieven dan afstand om daarvoor te kiezen, bijvoorbeeld een specialistische opleiding die elders niet wordt aangeboden, een opleiding of locatie van bijzondere kwaliteit, of eventueel een goede bereikbaarheid.

In beide modellen die de keuze voor een sector verklaren, worden de volgende controlevariabelen meegenomen: geslacht, herkomst, diploma vooropleiding, richting vooropleiding, leeftijd, leeftijd kwadraat en de interactietermen afstand ${ }^{*}$ vrouw en afstand*allochtoon. De interactietermen geven aan of vrouwen ten opzichte van mannen, en allochtonen ten opzichte van autochtonen, een andere afstandsgevoeligheid hebben bij de keuze voor een sector. Tevens wordt er gebruik gemaakt van binaire logistische regressiemodellen, waarmee de keuze voor een sector wordt geschat aan de hand van marginale effecten.

Tabel 4.4 geeft het effect weer van de exogene variabelen op de keuze voor een sector. Het verband tussen de afstand tot de dichtstbijzijnde technieklocatie en de keuze voor een technische opleiding is significant negatief. Hoe groter dus de afstand tussen de woning en de dichtstbijzijnde technieklocatie, hoe kleiner de kans dat een leerling kiest voor een technische opleiding. Dit is in overeenstemming met het eerder besproken 'distance deterrence effect'. Uit de interactieterm tussen geslacht en afstand tot de dichtstbijzijnde technieklocatie $(B=-$ 0,041 ) blijkt dat vrouwen nog afstandsgevoeliger zijn dan mannen bij de keuze voor techniek. Daarnaast blijkt dat leerlingen significant vaker voor techniek kiezen, als de afstand tot de dichtstbijzijnde economielocatie toeneemt $(B=0,017)$. Ook dit is in overeenstemming met de 'distance deterrence' theorie. Dit effect is sterker voor vrouwen: zij zijn veel meer dan mannen geneigd om voor een technische opleiding te kiezen, wanneer de afstand tot een economielocatie toeneemt $(0,017+0,078=0,095)$.

Zoals verwacht kiezen vrouwelijke leerlingen significant minder vaak voor techniek dan mannelijke leerlingen. Daarnaast kiezen allochtonen significant minder vaak voor techniek dan autochtonen. Naarmate een leerling ouder is, kiest hij vaker voor techniek. Uit de bijbehorende significant negatieve B-coëfficiënt van leeftijd kwadraat $(-0,002)$ blijkt echter dat deze invloed van leeftijd niet lineair is. Ook blijkt dat leerlingen die niet in het bezit zijn van een diploma van hun vooropleiding relatief vaak voor een technische vervolgopleiding kiezen. Leerlingen die een technische vooropleiding gevolgd hebben tijdens het vmbo, kiezen ook het vaakst voor een technische mboopleiding $(B=1,822)$, terwijl leerlingen die tijdens het vmbo een economische opleiding gevolgd hebben het minst vaak voor techniek kiezen $(B=-1,601)$. 
Tabel 4.4

Multinominale logistische regressie voor de kans dat een leerling kiest voor een opleidingssector, gegeven de afstanden tot de dichtstbijzijnde locaties voor techniek, economie en zorg

\begin{tabular}{|c|c|c|c|c|c|c|}
\hline & \multicolumn{3}{|c|}{ Techniek } & \multicolumn{3}{|c|}{ Zorg } \\
\hline & $\mathrm{B}$ & & S.E. & $\mathrm{B}$ & & S.E. \\
\hline Constante & $-2,018$ & $* * *$ & 0,368 & $-1,305$ & $* * *$ & 0,344 \\
\hline Afstand techniekloc.1 & $-0,013$ & ** & 0,005 & $-0,010$ & & 0,008 \\
\hline Geslacht*Afstand techniekloc. 1 & $-0,041$ & ** & 0,018 & 0,002 & & 0,010 \\
\hline HerkomstAfstand techniekloc. 1 & 0,018 & & 0,015 & $-0,017$ & & 0,013 \\
\hline Afstand economieloc. 1 & 0,017 & ** & 0,007 & 0,041 & $* * *$ & 0,010 \\
\hline Geslacht*Afstand economieloc. 1 & 0,078 & *** & 0,021 & $-0,004$ & & 0,013 \\
\hline HerkomstAfstand economieloc. 1 & 0,012 & & 0,023 & 0,021 & & 0,022 \\
\hline Afstand tot zorgloc. 1 & $-0,013$ & *** & 0,005 & $-0,036$ & $* * *$ & 0,007 \\
\hline Geslacht*Afstand tot zorgloc. 1 & $-0,024$ & ** & 0,011 & $-0,002$ & & 0,009 \\
\hline Herkomst*Afstand tot zorgloc. 1 & $-0,028$ & & 0,019 & $-0,004$ & & 0,019 \\
\hline Vrouw & $-1,942$ & $* * *$ & 0,094 & 2,013 & $* * *$ & 0,070 \\
\hline Allochtoon & $-0,727$ & *** & 0,103 & $-0,974$ & $* * *$ & 0,101 \\
\hline Leeftijd & 0,144 & *** & 0,028 & $-0,006$ & & 0,025 \\
\hline Leeftijd² $^{2}$ & $-0,002$ & *** & 0,000 & 0,001 & & 0,000 \\
\hline Geen diploma vooropleiding & 0,294 & $* * *$ & 0,058 & $-0,204$ & $* * *$ & 0,058 \\
\hline \multicolumn{7}{|l|}{ Richting vooropleiding } \\
\hline \multicolumn{7}{|l|}{ Algemeen (ref) } \\
\hline Groen & 0,397 & *** & 0,144 & 0,064 & & 0,134 \\
\hline Techniek & 1,822 & *** & 0,062 & $-0,449$ & $* * *$ & 0,116 \\
\hline Economie & $-1,601$ & $* * *$ & 0,094 & $-1,270$ & $* * *$ & 0,074 \\
\hline Zorg & $-0,714$ & *** & 0,133 & 1,086 & $* * *$ & 0,061 \\
\hline
\end{tabular}

Significantie: ${ }^{* * *}=p<0,01 ;{ }^{* *}=p<0,05 ;{ }^{*}=p<0,1 ; N=15.330$

Opmerking: De opleidingssector economie is de referentiecategorie.

Het rechter gedeelte van tabel 4.4 geeft de invloed weer van de verschillende onafhankelijke variabelen op de relatieve kans dat een leerling kiest voor een opleiding in de zorg. Uit de tabel kan geconcludeerd worden dat de kans dat een leerling voor zorg kiest significant afneemt wanneer de afstand tot de dichtstbijzijnde zorglocatie toeneemt $(B=-0,036)$. De interacties met geslacht en herkomst zijn beide niet significant. Neemt de afstand tot de dichtstbijzijnde economielocatie toe, dan kiest een leerling eerder voor zorg dan voor economie $(B=0,041)$. Beide coëfficiënten zijn in overeenstemming met het 'distance deterrence effect'.

In lijn der verwachting kiezen vrouwen significant meer dan mannen voor een zorgopleiding $(B=2,013)$. Allochtone leerlingen kiezen juist minder voor een zorgopleiding dan autochtone leerlingen. Leeftijd heeft geen significante invloed op de keuze voor de zorg. Leerlingen die geen diploma behaald hebben van hun vooropleiding komen ook significant minder vaak in de zorg terecht $(B=-0,204)$. Tevens blijkt zoals verwacht dat leerlingen die een vooropleiding in de zorg hebben gevolgd het vaakst kiezen voor een vervolgopleiding in deze 
richting. Leerlingen met een vooropleiding techniek of economie kiezen daarentegen significant minder vaak voor zorg.

Zoals eerder vermeld gaan we in tabel 4.5 na of, naast de dichtstbijzijnde locatie, ook de iets verder weg gelegen locaties invloed uitoefenen op de keuze voor een sector. Uit tabel 4.5 blijkt dat de kans dat een leerling voor techniek kiest significant afneemt wanneer de afstand tussen de dichtstbijzijnde en de op één na dichtstbijzijnde locatie waar techniek wordt aangeboden toeneemt $(B=-0,032)$. Naast de afstand tot de dichtstbijzijnde technieklocatie is dus ook de op één na dichtstbijzijnde technieklocatie significant van invloed op de keuze voor techniek. Dit is wederom conform het 'distance deterrence effect'. ${ }^{14}$ Tegen de verwachting in neemt de kans dat een leerling voor techniek kiest juist toe als de afstand tussen de op één na dichtstbijzijnde en de op twee na dichtstbijzijnde technieklocatie toeneemt $(B=0,013)$. Leerlingen kiezen dan vermoedelijk voor een verder weg gelegen locatie, omdat daar een specifieke richting binnen de techniek wordt aangeboden die niet op de dichter bij huis gelegen locaties aangeboden wordt en waarvoor zij bereid zijn verder te reizen.

Daarnaast is weer gekeken naar de invloed van de afstand tot economie- en zorglocaties op de keuze voor techniek. De kans dat een leerling kiest voor techniek neemt significant af, als de afstand tussen de op één na dichtstbijzijnde en de op twee na dichtstbijzijnde economielocatie toeneemt. Ook dit is opmerkelijk, want men zou verwachten dat wanneer deze afstand groter wordt, leerlingen minder snel geneigd zijn om voor economie te kiezen en dus eerder voor techniek. Een verklaring voor dit tegengestelde teken zou kunnen liggen in andere niet-waarneembare factoren die van invloed zijn op de locatiekeuze. Te denken valt bijvoorbeeld aan een betere bereikbaarheid die de aantrekkelijkheid van een verderaf gelegen locatie kan vergroten, of een betere onderwijskwaliteit op de betreffende locatie. De coëfficiënten en het significantieniveau van de controlevariabelen zijn in overeenstemming met die in tabel 4.4 en worden hier dan ook niet nader besproken.

14. Voor vrouwen en allochtonen zijn de effecten van de afstanden tot de op één na en op twee na dichtstbijzijnde locaties niet gespecificeerd naar geslacht en herkomst, omdat dit nauwelijks significante effecten opleverde, terwijl de tabellen er minder overzichtelijk door werden. 
Tabel 4.5

Multinominale logistische regressie voor de kans dat een leerling kiest voor een opleidingssector, gegeven de afstanden tot de drie dichtstbijzijnde locaties voor techniek, economie en zorg

\begin{tabular}{|c|c|c|c|c|c|c|}
\hline & \multicolumn{3}{|c|}{ Techniek } & \multicolumn{3}{|c|}{ Zorg } \\
\hline & $\mathrm{B}$ & & S.E. & $\mathrm{B}$ & & S.E. \\
\hline Constante & $-1,654$ & *** & 0,376 & $-1,345$ & & 0,352 \\
\hline Afstand technieklocatie 1 & $-0,021$ & ** & 0,010 & $-0,010$ & & 0,011 \\
\hline Geslacht*afstand techniekloc1 & $-0,044$ & ** & 0,019 & 0,002 & & 0,010 \\
\hline Herkomst ${ }^{\star}$ afstand techniekloc1 & 0,015 & & 0,015 & $-0,017$ & & 0,013 \\
\hline Afstand techloc2-techloc1 & $-0,032$ & *** & 0,008 & $-0,012$ & & 0,007 \\
\hline Afstand techloc3-techloc2 & 0,013 & $* * *$ & 0,004 & $-0,015$ & $* * *$ & 0,004 \\
\hline Afstand economielocatie 1 & 0,018 & & 0,013 & 0,060 & $* * *$ & 0,015 \\
\hline Geslacht*afstand ecoloc 1 & 0,069 & *** & 0,021 & $-0,011$ & & 0,013 \\
\hline Herkomst ${ }^{\star}$ afstand ecoloc1 & 0,013 & & 0,023 & 0,020 & & 0,022 \\
\hline Afstand ecoloc2-ecoloc1 & $-0,008$ & & 0,010 & 0,015 & & 0,010 \\
\hline Afstand ecoloc3-ecoloc2 & $-0,020$ & *** & 0,005 & 0,008 & * & 0,005 \\
\hline Afstand zorglocatie 1 & $-0,007$ & & 0,006 & $-0,056$ & $* * *$ & 0,008 \\
\hline Geslacht*afstand zorgloc1 & $-0,012$ & & 0,010 & 0,005 & & 0,009 \\
\hline Herkomst ${ }^{\star}$ afstand zorgloc1 & $-0,027$ & & 0,018 & $-0,003$ & & 0,019 \\
\hline Afstand zorgloc2-zorgloc1 & 0,010 & ** & 0,004 & $-0,018$ & $* * *$ & 0,004 \\
\hline Afstand zorgloc3-zorgloc2 & $-0,005$ & & 0,005 & 0,000 & & 0,005 \\
\hline Vrouw & $-1,941$ & *** & 0,095 & 2,032 & $* * *$ & 0,071 \\
\hline Allochtoon & $-0,664$ & $* * *$ & 0,105 & $-0,981$ & $* * *$ & 0,103 \\
\hline Leeftijd & 0,130 & *** & 0,028 & 0,000 & & 0,000 \\
\hline Leeftijd ${ }^{2}$ & $-0,002$ & *** & 0,000 & 0,000 & & 0,000 \\
\hline Geen diploma vooropleiding & 0,304 & $* * *$ & 0,059 & $-0,182$ & $* * *$ & 0,058 \\
\hline \multicolumn{7}{|l|}{ Richting vooropleiding } \\
\hline \multicolumn{7}{|l|}{ Algemeen (ref.) } \\
\hline Groen & 0,402 & *** & 0,145 & 0,073 & & 0,136 \\
\hline Techniek & 1,816 & $* * *$ & 0,062 & $-0,454$ & $* * *$ & 0,116 \\
\hline Economie & $-1,624$ & $* * *$ & 0,095 & $-1,235$ & $* * *$ & 0,074 \\
\hline Zorg & $-0,731$ & $* * *$ & 0,133 & 1,104 & $* * *$ & 0,062 \\
\hline
\end{tabular}

Significantie: ${ }^{* * *}=p<0,01 ;{ }^{* *}=p<0,05 ;{ }^{*}=p<0,1 ; N=15.330$.

Opmerking: De opleidingssector economie is de referentiecategorie.

In het rechter gedeelte van tabel 4.5 worden de resultaten weergegeven voor de sector zorg, waarbij economie andermaal de referentiecategorie is. Ook na het toevoegen van de nieuwe afstandsvariabelen neemt de kans dat een leerling kiest voor zorg significant af, wanneer de afstand tot de dichtstbijzijnde zorglocatie toeneemt $(B=-$ 0,056). De variabele die de invloed beschrijft van het verschil in afstand tussen de dichtstbijzijnde en de op één na dichtstbijzijnde zorglocatie is eveneens significant. Het negatieve teken wil zeggen dat leerlingen doorgaans minder snel voor een zorgopleiding kiezen als de afstand tussen de dichtstbijzijnde en de op één na dichtstbijzijnde zorglocatie toeneemt. 
Ook hier is gekeken naar de invloed van de afstand naar locaties waar alternatieve opleidingssectoren aangeboden worden. Wanneer de afstand tot de dichtstbijzijnde economielocatie toeneemt, vergroot dit de kans dat een leerling kiest voor een opleiding in de sector zorg $(B=0,060)$. Als de afstand tussen de op één na dichtstbijzijnde en de op twee na dichtstbijzijnde economielocatie toeneemt, kiezen leerlingen eveneens vaker voor een opleiding in de zorg. Bovengenoemde resultaten komen overeen met het 'distance deterrence effect'. Dit geldt echter niet voor het negatieve effect van de afstand tussen de op één na en op twee dichtstbijzijnde technieklocatie op de keuze voor een zorgopleiding. De coëfficiënten en het significantieniveau van de controlevariabelen zijn in overeenstemming met die in tabel 4.4 .

Uit de resultaten van tabellen 4.4 en 4.5 blijkt over het algemeen dat de afstanden tot de dichtstbijzijnde locaties de keuze voor een sector kunnen beïnvloeden. Dit geldt voor de leerlingen in onze onderzoekspopulatie in het bijzonder met betrekking tot de dichtstbijzijnde locatie van techniek, economie en zorg. Als de afstand tot een locatie met één van deze sectoren toeneemt, dan leidt dit er doorgaans toe dat minder leerlingen zullen kiezen voor de betreffende sector. Dit geldt niet voor de afstand tot de op twee na dichtstbijzijnde locatie van de betreffende sector. Voor deze locatie letten leerlingen kennelijk meer op andere zaken die van belang kunnen zijn bij de keuze van een sector, bijvoorbeeld de kwaliteit van de opleiding en de bereikbaarheid. Bovendien kunnen leerlingen kiezen voor een verder weg gelegen opleidingslocatie als daar een specifieke richting binnen een sector wordt aangeboden waarvoor leerlingen bereid zijn verder te reizen.

\subsection{Afstandsgevoeligheid in marginale effecten}

Om de interpreteerbaarheid van de resultaten van de analyses in de vorige paragraaf te verbeteren worden deze in tabel 4.6 uitgedrukt in marginale effecten. Zo kan geconcludeerd worden wat het effect van afstand is op de keuze voor een sector, wanneer de afstand tussen de woning van een leerling en een opleidingslocatie met één kilometer zou toenemen. De in tabel 4.6 weergegeven resultaten worden ontleend aan drie verschillende binaire logistische regressies. Hierin wordt telkens de kans geschat dat leerlingen kiezen voor een sector (ten opzichte van de kans dat zij niet kiezen voor deze sector). De resultaten worden per sector besproken.

Techniek

Wat betreft de keuze voor de sector techniek laten de marginale effecten zien wat de invloed is van de verschillende verklarende variabelen op de keuze voor een techniekopleiding. De referentiecategorie is hierbij de keuze voor een niet-technische studie. Zo vinden we dat de kans dat een leerling een technische studie gaat volgen met $0,3 \%$ afneemt wanneer de afstand tussen zijn of haar woning en de dichtstbijzijnde opleidingslocatie waar techniek wordt aangeboden met één kilometer toeneemt. Dit betekent dat de kans dat een leerling voor techniek kiest met $6 \%$ afneemt als de leerling 20 kilometer verder van een technieklocatie woont. Ook wat betreft de afstand tot de op één na dichtst bij huis gelegen technieklocatie vinden we een significant negatief effect op de keuze voor techniek, i.e. hoe groter de afstand tussen de woning en de op één na dichtstbijzijnde technieklocatie, hoe kleiner de kans dat een leerling voor techniek kiest. Anders dan verwacht, vinden we voor de derde locatie een positief significant verband van afstand op de keuze voor techniek. Dit betekent dat hier de eerder besproken niet-waarneembare factoren een rol spelen. Te denken valt aan de keuze voor een specifieke techniekopleiding die niet op de dichterbij gelegen technieklocaties wordt aangeboden. Het verband is in feite andersom: doordat de betreffende technieklocatie iets bijzonders te bieden heeft komen leerlingen van ver weg gelegen regio's, waarbij afstand voor deze gemotiveerde groep van leerlingen een zeer geringe rol speelt. Hoe verder weg een dergelijke locatie ligt, hoe aantrekkelijker deze locatie voor leerlingen is. Gerelateerd hieraan blijken leerlingen ook minder voor techniek te kiezen als zij verder van de op twee na dichtstbijzijnde economielocatie wonen. Tevens wordt er een significant positief effect gevonden tussen de afstand tot de op één na dichtstbijzijnde zorglocatie en de keuze voor techniek. Dus verder weg deze zorglocatie ligt, hoe vaker voor techniek gekozen wordt. 
Ook wat betreft de controlevariabelen zijn de effecten op de keuze voor techniek beter te interpreteren dan in de eerdere tabellen. Ceteris paribus is de kans dat vrouwen voor techniek kiezen 35,5\% kleiner dan bij mannen. Allochtonen kiezen op hun beurt iets minder voor techniek dan autochtonen (-5,5\%). Oudere leerlingen kiezen doorgaans vaker voor techniek, elk jaar neemt deze kans met zo'n $2 \%$ toe. Zoals blijkt uit het negatieve teken van de variabele voor leeftijd kwadraat, is dit effect echter non-lineair. Leerlingen die niet in het bezit zijn van een diploma van hun vooropleiding hebben $5,2 \%$ meer kans om een technische studie te volgen. Ook kan geconcludeerd worden dat degenen die een technische vooropleiding hebben genoten 35,5\% meer kans hebben om in het MBO ook een technische studie te gaan volgen dan degenen met een algemene vooropleiding.

Tabel 4.6

De keuze voor techniek, economie of zorg, marginale effecten op basis van binaire logistische regressies

\begin{tabular}{|c|c|c|c|c|c|c|}
\hline & \multicolumn{2}{|c|}{$\begin{array}{c}\text { Techniek vs. niet- } \\
\text { techniek }\end{array}$} & \multicolumn{2}{|c|}{$\begin{array}{c}\text { Economie vs. niet- } \\
\text { economie }\end{array}$} & \multicolumn{2}{|c|}{$\begin{array}{l}\text { Zorg vs. niet- } \\
\text { zorg }\end{array}$} \\
\hline Afstand technieklocatie 1 & $-0,003$ & ** & 0,004 & ** & $-0,001$ & \\
\hline Afstand technieklocatie 2-1 & $-0,004$ & $* * *$ & 0,005 & $* * *$ & $-0,001$ & \\
\hline Afstand technieklocatie 3-2 & 0,002 & $* * *$ & 0,000 & & $-0,003$ & *** \\
\hline Afstand economielocatie 1 & 0,001 & & $-0,009$ & *** & 0,008 & *** \\
\hline Afstand economielocatie 2-1 & $-0,002$ & & $-0,001$ & & 0,003 & \\
\hline Afstand economielocatie 3-2 & $-0,003$ & $* * *$ & 0,001 & & 0,003 & *** \\
\hline Afstand zorglocatie 1 & 0,000 & & 0,007 & $* * *$ & $-0,009$ & *** \\
\hline Afstand zorglocatie 2-1 & 0,002 & $* * *$ & 0,001 & & $-0,004$ & *** \\
\hline Afstand zorglocatie 3-2 & $-0,001$ & & 0,001 & & 0,000 & \\
\hline Vrouw & $-0,355$ & $* * *$ & $-0,133$ & $* * *$ & 0,454 & *** \\
\hline Allochtoon & $-0,055$ & $* * *$ & 0,198 & *** & $-0,138$ & *** \\
\hline Leeftijd & 0,019 & $* * *$ & $-0,013$ & $* * *$ & $-0,005$ & \\
\hline Leeftijd $^{2}$ & $-0,000$ & $* * *$ & 0,000 & & 0,000 & ** \\
\hline Geen diploma vooropleiding & 0,052 & $* * *$ & $-0,012$ & & $-0,044$ & *** \\
\hline \multicolumn{7}{|l|}{ Richting vooropleiding } \\
\hline Algemeen (ref.) & - & & - & & - & \\
\hline Groen & 0,058 & ** & $-0,047$ & ** & $-0,004$ & \\
\hline Techniek & 0,355 & $* * *$ & $-0,282$ & $* * *$ & $-0,219$ & *** \\
\hline Economie & $-0,139$ & $* * *$ & 0,335 & *** & $-0,157$ & *** \\
\hline Zorg & $-0,137$ & $* * *$ & $-0,170$ & $* * *$ & 0,258 & *** \\
\hline $\mathrm{N}$ & 15.330 & & 15.330 & & 15.330 & \\
\hline Pseudo $\mathrm{R}^{2}$ & 0,407 & & 0,141 & & 0,377 & \\
\hline Log likelihood & $-5534,28$ & & $-8574,56$ & & $-6164,94$ & \\
\hline
\end{tabular}

Significantie: ${ }^{* * *}=p<0,01 ;{ }^{* *}=p<0,05 ;{ }^{*}=p<0,1 ; N=15.330$. 


\section{Economie}

De keuze voor economie blijkt eveneens af te nemen naarmate een leerling verder van de dichtstbijzijnde economielocatie vandaan woont. De kans dat een leerling voor economie kiest, neemt elke kilometer die hij verder van de dichtstbijzijnde economielocatie woont met $0,9 \%$ af. Wanneer een leerling dus op een afstand van twintig kilometer woont ten opzichte van de voor hem dichtstbijzijnde economielocatie, dan verkleint dit de kans om voor economie te kiezen met $18 \%$. Er wordt geen significant effect gevonden van de afstand tot de op één na dichtstbijzijnde, alsook de afstand tot de op twee na dichtstbijzijnde, economielocatie op de keuze voor een opleiding in de sector economie. Als de afstand tot de dichtstbijzijnde technieklocatie toeneemt, neemt de kans dat leerlingen voor economie kiezen significant toe. Voor elke kilometer dat zij verder van deze technieklocatie vandaan wonen, neemt de kans dat zij voor een economische studie kiezen met $0,4 \%$ toe. Tevens geldt dat hoe groter de afstand tot de op één na dichtstbijzijnde technieklocatie, hoe eerder een leerling voor economie zal kiezen. Ook de invloed van de afstand tot de dichtstbijzijnde zorglocatie is significant positief, wat betekent dat leerlingen eerder voor economie zullen kiezen indien zij verder moeten reizen naar de dichtstbijzijnde zorglocatie.

De kans dat vrouwelijke leerlingen voor economie kiezen is $13,3 \%$ lager dan voor mannelijke leerlingen. Allochtonen kiezen juist relatief vaak voor economie. De kans dat zij voor economie kiezen is bijna $20 \%$ hoger dan voor autochtonen. Economieleerlingen zijn doorgaans ook wat jonger dan leerlingen van techniek of zorg. Zoals verwacht, kiezen degenen met een vooropleiding economie ook het meest voor deze sector in het MBO. Zo heeft een leerling met een economische vooropleiding 33,5\% meer kans om in het MBO ook een economische opleiding te volgen dan iemand met een algemene vooropleiding.

\section{Zorg}

De laatste kolom in tabel 4.6 laat de marginale effecten zien voor de kans dat leerlingen kiezen voor zorg (ten opzichte van de kans dat zij niet voor zorg kiezen). De afstand tot de dichtstbijzijnde zorglocatie heeft een significant negatief effect op de keuze voor zorg. Hoe groter deze afstand tot de dichtstbijzijnde zorglocatie, hoe kleiner de kans dat een leerling kiest voor zorg. Dit effect $(-0,009)$ is even groot als het effect van afstand voor economieleerlingen. Wanneer een leerling op een afstand van 20 kilometer woont ten opzichte van de dichtstbijzijnde zorglocatie, dan neemt de kans om voor zorg te kiezen met $18 \%$ af. Ook het effect van de op één na dichtstbijzijnde zorglocatie is significant negatief. Wat betreft het effect van de afstand tot nabijgelegen economielocaties, blijkt dat er een significant positief effect gevonden wordt voor de afstand tot de dichtstbijzijnde en de op twee na dichtstbijzijnde economielocatie op de kans om voor zorg te kiezen. Verder wordt er, in tegenstelling tot de verwachting, een significant negatief effect gevonden van de afstand tot de op twee na dichtstbijzijnde technieklocatie op de keuze voor zorg. Hier spelen waarschijnlijk andere niet-waarneembare factoren een rol.

Wat betreft de marginale effecten van de controlevariabelen is het geen verrassing dat vrouwelijke leerlingen vaker een opleiding in de sector zorg volgen dan mannelijke leerlingen. De kans dat vrouwen een zorgopleiding volgen is zelfs $45,4 \%$ hoger dan dat mannen een dergelijke opleiding volgen. Allochtonen kiezen juist minder voor zorg dan autochtonen (-13,8\%). Leerlingen die geen diploma van hun vooropleiding behaald hebben, kiezen minder vaak voor zorg $(-4,4 \%)$. De kans dat leerlingen met een vooropleiding richting zorg ook in het MBO voor zorg kiezen is $25,8 \%$ hoger in vergelijking met leerlingen met een algemene vooropleiding.

In het algemeen kan op basis van tabel 4.6 geconcludeerd worden dat techniekleerlingen minder afstandsgevoelig zijn dan economie- en zorgleerlingen, omdat het marginale effect van afstand voor eerstgenoemde groep het kleinst is. Verder blijkt dat leerlingen doorgaans eerder voor economie kiezen, wanneer technieklocaties verder weg liggen. Tevens blijkt dat leerlingen eerder voor zorg zullen kiezen, wanneer economielocaties verder weggelegen zijn. Als de afstand tot zorglocaties toeneemt, kiezen leerlingen vaker voor economie en in mindere mate voor techniek. 


\subsection{Afstandsgevoeligheid in marginale effecten naar geslacht en herkomst}

In de tabellen 4.7 tot en met 4.9 worden de resultaten uit tabel 4.6 verbijzonderd op basis van geslacht en herkomst. Zo kan voor verschillende groepen (i.e. mannelijke autochtonen, mannelijke allochtonen, vrouwelijke autochtonen en vrouwelijke allochtonen) de invloed van afstand op de keuze voor respectievelijk techniek, economie of zorg in kaart gebracht worden.

Techniek

Tabel 4.7 presenteert voor de vier afzonderlijke groepen de marginale effecten van afstand op de keuze voor techniek (ten opzichte van de keuze voor niet-techniek). Voor elke afzonderlijke groep is de invloed van afstand op de keuze voor techniek geschat aan de hand van een binaire logistische regressieanalyse. In de eerste kolom staan bovendien de marginale effecten voor de totale groep, welke overeenkomen met de marginale effecten van de keuze voor techniek in de eerste kolom van tabel 4.6. Zoals verwacht is het effect van afstand op de studiekeuze minder significant voor de afzonderlijke groepen dan voor de totale groep leerlingen, omdat het dan om kleinere aantallen gaat. Dit geldt met name voor mannelijke en vrouwelijke allochtonen. Interessant is vooral dat de negatieve invloed van afstand op de keuze voor techniek vooral te wijten is aan het keuzegedrag van vrouwelijke autochtonen. Voor elke kilometer die de dichtstbijzijnde technieklocatie verder weg gelegen is, neemt de kans dat zij voor techniek kiezen met $0,2 \%$ af. Voor de overige groepen blijkt dit effect niet significant te zijn. Mannen, ongeacht allochtoon of autochtoon, kiezen minder vaak voor techniek als de op één na dichtstbijzijnde technieklocatie verder weg ligt. Mannelijke autochtonen kiezen significant vaker voor techniek wanneer de op twee na dichtstbijzijnde technieklocatie verder weg ligt. Dit kan zeer waarschijnlijk verklaard worden door de eerder besproken niet-waarneembare factoren.

Vrouwelijke autochtonen laten zich van alle groepen het meest beïnvloeden door de afstand tot de dichtstbijzijnde economielocatie. Als deze afstand tot de dichtstbijzijnde economielocatie namelijk groter is, blijken zij significant vaker voor techniek te kiezen. Voor mannelijke autochtonen zijn de resultaten moeilijker te verklaren. Als de afstand tot de op één na en de op twee na dichtstbijzijnde economielocatie toeneemt, blijken zij significant minder vaak voor techniek te kiezen, terwijl een positief teken hier meer plausibel zou zijn. Daarnaast blijkt dat mannelijke autochtonen significant vaker voor techniek kiezen, naarmate de op één na dichtstbijzijnde zorglocatie verder weg ligt. 
Tabel 4.7

De keuze voor techniek versus niet-techniek (i.e. economie of zorg), marginale effecten op basis van binaire logistische regressies

\begin{tabular}{|c|c|c|c|c|c|c|c|}
\hline & \multicolumn{2}{|c|}{ Totale groep } & \multicolumn{2}{|c|}{$\begin{array}{l}\text { Mannelijke } \\
\text { autochtoon }\end{array}$} & $\begin{array}{l}\text { Mannelijke } \\
\text { allochtoon }\end{array}$ & $\begin{array}{l}\text { Vrouwelijke } \\
\text { autochtoon }\end{array}$ & $\begin{array}{l}\text { Vrouwelijke } \\
\text { allochtoon }\end{array}$ \\
\hline Afstand techniekloc. 1 & $-0,003$ & ** & $-0,002$ & & 0,009 & $-0,002 * * *$ & $-0,002$ \\
\hline Afstand techniekloc. 2-1 & $-0,004$ & $* * *$ & $-0,004$ & * & $-0,034 \quad * * *$ & $-0,000$ & 0,001 \\
\hline Afstand techniekloc. 3-2 & 0,002 & $* * *$ & 0,005 & $* * *$ & $-0,003$ & 0,000 & 0,000 \\
\hline Afstand economieloc. 1 & 0,001 & & $-0,001$ & & $-0,017$ & $0,002 * * *$ & 0,002 \\
\hline Afstand economieloc. 2-1 & $-0,002$ & & $-0,005$ & * & $-0,015$ & 0,001 & 0,000 \\
\hline Afstand economieloc. 3-2 & $-0,003$ & $* * *$ & $-0,007$ & $* * *$ & 0,001 & 0,000 & $-0,000$ \\
\hline Afstand zorgloc. 1 & 0,000 & & 0,001 & & 0,005 & 0,000 & 0,000 \\
\hline Afstand zorgloc. 2-1 & 0,002 & $* * *$ & 0,002 & ** & 0,005 & 0,000 & 0,001 \\
\hline Afstand zorgloc. 3-2 & $-0,001$ & & $-0,000$ & & $-0,005$ & $-0,000$ & $-0,000$ \\
\hline Controle variabelen & ja & & ja & & ja & ja & ja \\
\hline $\mathrm{N}$ & 15.330 & & 7.426 & & 754 & 6.440 & 710 \\
\hline Pseudo $\mathrm{R}^{2}$ & 0,407 & & 0,205 & & 0,229 & 0,121 & 0,262 \\
\hline Log likelihood & $-5534,28$ & & $-4071,91$ & & $-380,37$ & $-881,14$ & $-72,42$ \\
\hline
\end{tabular}

Significantie: ${ }^{* * *}=p<0,01 ;{ }^{* *}=p<0,05 ;{ }^{*}=p<0,1 ; N=15.330$.

Noot: Als controlevariabelen zijn dezelfde variabelen in de schattingen meegenomen als in tabel 4.6.

\section{Economie}

Tabel 4.8 presenteert de resultaten van dezelfde binaire logistische regressieanalyses als in tabel 4.7 , ditmaal betreft het echter de marginale effecten voor de keuze voor economie (ten opzichte van de keuze voor een nieteconomische opleiding). Als de afstand tot nabijgelegen economielocaties toeneemt, zijn het vooral de vrouwelijke allochtone leerlingen die minder snel geneigd zijn voor economie te kiezen. De keuze van deze groep voor economie wordt significant negatief beïnvloed door de afstand naar elk van de drie dichtstbijzijnde economielocaties. De kans dat vrouwelijke allochtonen leerlingen voor economie kiezen neemt elke kilometer die zij verder moeten reizen naar de dichtstbijzijnde economielocatie zelfs met maar liefst $4,9 \%$ af. Ook autochtone leerlingen (zowel mannelijk als vrouwelijk) kiezen significant minder vaak voor economie als de voor hen dichtstbijzijnde economielocatie verder weg ligt. Voor mannelijke allochtonen lijkt de afstand tot economielocaties geen obstakel te zijn om voor economie te kiezen. Voor mannelijke autochtonen geldt dat zij vaker voor economie kiezen als de afstand tot de op twee na dichtstbijzijnde economielocatie toeneemt. Dit wordt waarschijnlijk verklaard door andere niet-waarneembare factoren.

Mannelijke autochtonen, mannelijke allochtonen en vrouwelijke allochtonen kiezen bovendien in bepaalde gevallen vaker voor economie als de afstand tussen hun woning en technieklocaties toeneemt. Tevens kan voor vrouwelijke leerlingen, ongeacht de herkomst, en voor mannelijke autochtonen geconcludeerd worden dat zij vaker voor economie kiezen, wanneer de dichtstbijzijnde locatie waar zorg aangeboden wordt verder weg ligt. 
Tabel 4.8

De keuze voor economie versus niet-economie (i.e. techniek of zorg), marginale effecten op basis van binaire logistische regressies

\begin{tabular}{|c|c|c|c|c|c|c|c|c|c|c|}
\hline & Totale gr & sep & \multicolumn{2}{|c|}{$\begin{array}{l}\text { Mannelijke } \\
\text { autochtoon }\end{array}$} & \multicolumn{2}{|c|}{$\begin{array}{c}\text { Mannelijke } \\
\text { allochtoon }\end{array}$} & \multicolumn{2}{|c|}{$\begin{array}{l}\text { Vrouwelijke } \\
\text { autochtoon }\end{array}$} & \multicolumn{2}{|c|}{$\begin{array}{l}\text { Vrouwelijke } \\
\text { allochtoon }\end{array}$} \\
\hline Afstand techniekloc. 1 & 0,004 & $* *$ & 0,004 & * & $-0,014$ & & 0,002 & & 0,023 & $* * *$ \\
\hline Afstand techniekloc. 2-1 & 0,005 & *** & 0,002 & & 0,037 & $* * *$ & 0,002 & & 0,003 & \\
\hline Afstand techniekloc. 3-2 & 0,000 & & $-0,002$ & ** & 0,005 & * & 0,001 & & 0,006 & * \\
\hline Afstand economieloc. 1 & $-0,009$ & $* * *$ & $-0,007$ & ** & 0,023 & * & $-0,009$ & *** & $-0,049$ & $* * *$ \\
\hline Afstand economieloc. 2-1 & $-0,001$ & & $-0,000$ & & 0,018 & * & $-0,002$ & & $-0,021$ & ** \\
\hline Afstand economieloc. 3-2 & 0,001 & & 0,003 & $* * *$ & $-0,001$ & & $-0,000$ & & $-0,010$ & ** \\
\hline Afstand zorgloc. 1 & 0,007 & $* * *$ & 0,005 & $* * *$ & $-0,005$ & & 0,009 & $* * *$ & 0,021 & $\star * *$ \\
\hline Afstand zorgloc. 2-1 & 0,001 & & 0,001 & & $-0,005$ & & 0,002 & * & 0,002 & \\
\hline Afstand zorgloc. 3-2 & 0,001 & & 0,001 & & 0,004 & & $-0,000$ & & 0,004 & \\
\hline Controle variabelen & ja & & ja & & ja & & ja & & ja & \\
\hline $\mathrm{N}$ & 15.330 & & 7.426 & & 754 & & 6.440 & & 710 & \\
\hline Pseudo $\mathrm{R}^{2}$ & $\begin{array}{r}0,141 \\
-\end{array}$ & & 0,157 & & 0,217 & & 0,092 & & 0,166 & \\
\hline Log likelihood & 8574,56 & & $-4133,78$ & & $-398,84$ & & $-3503,99$ & & $-404,71$ & \\
\hline
\end{tabular}

Significantie: ${ }^{\star \star *}=p<0,01 ;{ }^{* *}=p<0,05 ;{ }^{*}=p<0,1 ; N=15.330$

Noot: Als controlevariabelen zijn dezelfde variabelen in de schattingen meegenomen als in tabel 4.6.

Zorg

Ook de invloed van afstand op de keuze voor zorg (ten opzichte van niet-zorg) in tabel 4.9 wordt voor de verschillende groepen weergegeven aan de hand van marginale effecten. Wederom is het effect van afstand het meest negatief voor vrouwelijke allochtonen. Met elke kilometer die zij verder van de dichtstbijzijnde zorglocatie wonen, neemt de kans dat zij voor zorg kiezen met 1,3\% af. Ook het effect van de afstand tot de op één na dichtstbijzijnde zorglocatie is significant negatief voor deze groep. Voor mannelijke autochtonen en vrouwelijke autochtonen vinden we eveneens significant negatieve effecten van de afstand tot de twee dichtstbijzijnde zorglocaties.

Voor de vier onderscheiden subgroepen blijkt er een significant negatief effect te zijn van de afstand tot de op twee na dichtstbijzijnde technieklocatie op de keuze voor de zorg, wat contra-intuïtief is. Vrouwelijke allochtonen en mannelijke autochtonen kiezen doorgaans wel vaker voor zorg als de afstand tot locaties waar economie aangeboden wordt toeneemt. 
Tabel 4.9

De keuze voor zorg versus niet-zorg (i.e. techniek of economie), marginale effecten op basis van binaire logistische regressies

\begin{tabular}{|c|c|c|c|c|c|c|c|c|c|}
\hline & \multicolumn{2}{|c|}{ Totale groep } & \multicolumn{2}{|c|}{$\begin{array}{l}\text { Mannelijke } \\
\text { autochtoon }\end{array}$} & $\begin{array}{l}\text { Mannelijke } \\
\text { allochtoon }\end{array}$ & \multicolumn{2}{|c|}{$\begin{array}{l}\text { Vrouwelijke } \\
\text { autochtoon }\end{array}$} & \multicolumn{2}{|c|}{$\begin{array}{l}\text { Vrouwelijke } \\
\text { allochtoon }\end{array}$} \\
\hline Afstand techniekloc. 1 & $-0,001$ & & $-0,000$ & & 0,003 & 0,001 & & $-0,014$ & \\
\hline Afstand techniekloc. 2-1 & $-0,001$ & & 0,001 & * & $-0,001$ & $-0,002$ & & $-0,007$ & \\
\hline Afstand techniekloc. 3-2 & $-0,003$ & $* * *$ & $-0,002$ & $* * *$ & $-0,001 *$ & $-0,002$ & * & $-0,008$ & ** \\
\hline Afstand economieloc. 1 & 0,008 & $* * *$ & 0,004 & $* * *$ & $-0,004$ & 0,005 & & 0,027 & $* *$ \\
\hline Afstand economieloc. 2-1 & 0,003 & & 0,002 & ** & $-0,003$ & 0,000 & & 0,013 & \\
\hline Afstand economieloc. 3-2 & 0,003 & $* * *$ & 0,002 & $* \star *$ & $-0,000$ & 0,000 & & 0,010 & ** \\
\hline Afstand zorgloc. 1 & $-0,009$ & $* * *$ & $-0,004$ & $* * *$ & $-0,002$ & $-0,009$ & $* * *$ & $-0,013$ & $* *$ \\
\hline Afstand zorgloc. 2-1 & $-0,004$ & $* * *$ & $-0,002$ & $* * *$ & $-0,000$ & $-0,003$ & $* * *$ & $-0,006$ & * \\
\hline Afstand zorgloc. 3-2 & 0,000 & & $-0,000$ & & 0,001 & 0,001 & & $-0,005$ & \\
\hline Controle variabelen & ja & & ja & & ja & ja & & ja & \\
\hline $\mathrm{N}$ & 15.330 & & 7.426 & & 754 & 6.440 & & 710 & \\
\hline Pseudo $\mathrm{R}^{2}$ & 0,377 & & 0,113 & & 0,163 & 0,102 & & 0,166 & \\
\hline Log likelihood & $-6164,94$ & & $-1929,07$ & & $-118,53$ & $-3638,03$ & & $-398,34$ & \\
\hline
\end{tabular}

Significantie: ${ }^{* * *}=p<0,01 ;{ }^{* *}=p<0,05 ;{ }^{*}=p<0,1 ; N=15.330$.

Noot: Als controlevariabelen zijn dezelfde variabelen in de schatting meegenomen als in tabel 4.6.

\section{Conclusies}

In het voorliggende rapport wordt de afstandsgevoeligheid van leerlingen van het voortgezet onderwijs onderzocht bij hun keuze voor een opleiding in het mbo. Het rapport gaat zowel in op de rol van afstand bij de keuze voor een opleidingslocatie als op de aldaar aangeboden opleidingssectoren. Er worden drie sectoren onderscheiden: techniek, economie en zorg. Voor het onderzoek is gebruik gemaakt van administratieve data afkomstig van vijf regionale opleidingscentra (ROC's) waarvan de hoofdvestiging gelegen is in het oosten van Noord-Brabant, of Noord- en Midden-Limburg. ${ }^{15}$ De dataset bevat gegevens van ruim 15.600 eerstejaarsleerlingen die geregistreerd waren bij één van deze vijf ROC's in het voorjaar van 2005 (schooljaar 2004/2005), exclusief contractonderwijs en volwasseneneducatie. Van al deze mbo-leerlingen is met behulp van Google Maps de afstand berekend tussen de woonlocatie en alle binnen het onderzoeksgebied gelegen opleidingslocaties. Leerlingen kunnen in deze studie kiezen uit 31 verschillende opleidingslocaties van de vijf ROC's. Op elk van deze locaties wordt ofwel één opleidingssector aangeboden ofwel een combinatie van deze sectoren. Op 19 van de 31 opleidingslocaties worden er technische opleidingen aangeboden, 17 locaties bieden economische opleidingen aan en 15 locaties bieden zorgopleidingen aan.

15. Het gaat om respectievelijk ROC Gilde Opleidingen, ROC Eindhoven, ROC Ter AA, ROC Koning Willem I College en ROC De Leijgraaf.

40 
De keuze voor een studie wordt bepaald door zowel persoonlijke factoren als omgevingsfactoren. Tot de persoonlijk factoren worden onder andere gerekend geslacht, herkomst en leeftijd. Voorbeelden van omgevingsfactoren zijn kwaliteit, imago en grootte van de opleiding(slocatie), de invloed van vrienden, ouders en kennissen, maar ook de afstand en bereikbaarheid van de opleidingslocatie. De invloed van de achtergrondkenmerken en de afstandsgevoeligheid van mbo-leerlingen op de keuze van een opleidingslocatie en sector wordt in deze studie geschat aan de hand van logistische regressiemodellen.

Over de invloed van reisafstand op de keuze voor een opleidingssector is slechts weinig bekend uit de literatuur. Duidelijk is wel dat de kans op geografische mobiliteit (i.e. pendelen of verhuizen) kleiner is als de afstand waarop deze betrekking heeft groter is. Deze afstandsgevoeligheid of -afhankelijkheid wordt in de Angelsaksische economische literatuur aangeduid met de term 'distance deterrence'. In het algemeen laten empirische studies een negatief verband zien tussen afstand en de keuze voor een opleidingslocatie. De ruimtelijke spreiding van de opleidingslocaties kan dus van invloed zijn op de keuze voor een bepaalde opleiding.

In de empirische studies wordt vaak buiten beschouwing gelaten dat er meerdere onderwijsinstellingen in de omgeving van de onderzochte school of universiteit liggen. Deze zogenaamde 'intervening opportunities' gelden als mogelijke alternatieven die het keuzeproces van leerlingen kunnen beïnvloeden. Aangezien de alternatieve opleidingslocaties in dit rapport als keuzemogelijkheden meegenomen worden, levert de empirische analyse een belangrijke bijdrage aan de bestaande literatuur.

Uit de beschrijvende analyse van de gebruikte dataset kwam naar voren dat leerlingen uit de sector techniek gemiddeld de grootste afstand afleggen naar hun opleidingslocatie $(20,4 \mathrm{~km})$, gevolgd door leerlingen uit de sector economie $(19,7 \mathrm{~km})$. Leerlingen die een zorgopleiding volgen, leggen gemiddeld de kortste afstand af $(17,7 \mathrm{~km})$. In het algemeen kiezen jonge leerlingen (i.e. <25 jaar) in vergelijking met oudere leerlingen vaker voor een opleidingslocatie die dichter bij huis ligt. Mannelijke leerlingen leggen een grotere afstand naar hun opleidingslocatie af $(20,3 \mathrm{~km})$ dan vrouwelijke leerlingen $(18,0 \mathrm{~km})$. Autochtone leerlingen leggen met 19,6 kilometer gemiddeld bijna 4 kilometer meer af dan allochtone leerlingen (15,7 km). De afstand die eerstejaars mbo-leerlingen afleggen naar hun opleidingslocatie blijkt ook te verschillen per vooropleiding. Leerlingen met een algemene vooropleiding (vmbo theorie of havo) leggen gemiddeld de grootste afstand af naar hun huidige opleidingslocatie $(21,2 \mathrm{~km})$. Van de overige vooropleidingen is de gemiddelde enkele reisafstand naar de opleidingslocatie $18,4 \mathrm{~km}$ voor techniek, $18,0 \mathrm{~km}$ voor groen, $17,0 \mathrm{~km}$ voor zorg en $15,5 \mathrm{~km}$ voor economie.

Verder blijkt dat in de onderzochte regio het grootste deel van de eerstejaars mbo-leerlingen (ruim 23\%) kiest voor de opleidingslocatie die het dichtst bij huis gelegen is. Van de techniekleerlingen gaat een kleiner gedeelte naar de dichtstbijzijnde locatie $(16,2 \%)$ dan van de leerlingen uit de sectoren economie $(27,8 \%)$ en zorg $(24,6 \%)$. Als er bij de keuze van leerlingen voor een bepaalde sector rekening wordt gehouden met de sectoren die op een locatie worden aangeboden (techniek, economie en/of zorg) dan blijkt een groter percentage leerlingen te kiezen voor de dichtstbijzijnde mogelijkheid om de betreffende sector te volgen. Zo kiest $35 \%$ van alle leerlingen die een technische opleiding volgen voor de dichtstbijzijnde technieklocatie. Voor de economie- en zorgleerlingen ligt dit percentage zelfs nog hoger. Van alle economieleerlingen kiest $40,4 \%$ voor de dichtstbijzijnde economielocatie, en van alle zorgleerlingen kiest zelfs $45,1 \%$ voor de dichtstbijzijnde zorglocatie.

Uit de empirische analyse in dit rapport blijkt duidelijk dat er sprake is van een 'distance deterrence' effect bij leerlingen ten aanzien van de keuze voor een opleidingslocatie. Naarmate een leerling verder van een locatie vandaan woont, zal hij/zij minder snel voor deze locatie kiezen. Als de opleidingslocaties in het onderzoeksgebied door middel van factoranalyse geclusterd worden in vijf regio's, op basis van de afstand die leerlingen naar deze locaties afleggen, blijkt eveneens dat als de afstand tot de betreffende regio toeneemt, de kans afneemt dat leerlingen in die regio gaan studeren (ten opzichte van referentieregio Eindhoven/Helmond). Dit is in lijn met de verwachtingen en geldt voor elk van de vier overige regio's. Tegelijkertijd blijkt dat wanneer de afstand tot de referentieregio toeneemt, de kans dat leerlingen in elk van de andere regio's gaan studeren significant toeneemt. 
Naast de invloed van afstand op de locatiekeuze is ook de invloed van afstand op de keuze voor een sector onderzocht. De keuze voor een opleiding in de sector techniek, economie of zorg wordt beïnvloed door de afstanden tot de dichtstbijzijnde locaties en het aanbod van de sectoren op de betreffende opleidingslocaties. Dit geldt voor de leerlingen in de onderzoekspopulatie heel duidelijk met betrekking tot de dichtstbijzijnde locaties van techniek, economie en zorg. Als de reisafstand tot een opleidingslocatie waar bijvoorbeeld techniek wordt aangeboden toeneemt, ten opzichte van de reisafstand tot locaties waar geen techniek wordt aangeboden, dan leidt dit ertoe dat minder leerlingen zullen kiezen voor een technische studie. Hetzelfde effect wordt gevonden voor economie en zorg, Een opleidingslocatie waar slechts één bepaalde sector wordt aangeboden, leidt er dus toe dat leerlingen in de directe omgeving van deze locatie een grotere kans hebben om voor deze sector te kiezen. Dit geldt in beduidend mindere mate voor de afstand tot de op twee na dichtstbijzijnde locatie van de betreffende sector. Bij de keuze voor deze locatie letten leerlingen kennelijk meer op andere zaken die van belang zijn bij de keuze van een sector, bijvoorbeeld de kwaliteit van de opleiding en de bereikbaarheid. Bovendien kunnen leerlingen heel bewust kiezen voor een specifieke richting binnen een sector (bijv. werktuigbouwkunde binnen techniek). Om deze specifieke richting te kunnen volgen, zijn zij dan bereid om verder te reizen.

Daarnaast wordt de afstandsgevoeligheid van leerlingen bij de keuze voor een studie in het MBO in deze studie uitgedrukt in marginale effecten. Hierdoor zijn de resultaten eenvoudiger te interpreteren. In het algemeen kan geconcludeerd worden dat techniekleerlingen minder afstandsgevoelig zijn dan economie- en zorgleerlingen. Als de afstand die een gemiddelde techniekleerling moet afleggen naar de voor de leerling dichtstbijzijnde locatie waar techniek wordt aangeboden met één kilometer toeneemt, neemt de kans dat de leerling voor een technische opleiding zal kiezen met $0,3 \%$ af. De kans dat een leerling voor techniek kiest neemt dus met $6 \%$ af als deze leerling 20 kilometer verder weg woont van de dichtstbijzijnde technieklocatie. Voor zowel economieleerlingen als leerlingen uit de zorg is het effect groter. Voor hen geldt dat iedere kilometer die zij verder van de dichtstbijzijnde locatie wonen de kans voor de keuze voor economie of zorg $0,9 \%$ doet afnemen. Als zij 20 kilometer verder wonen van de dichtstbijzijnde locatie waar deze opleidingen worden aangeboden dan neemt de kans om voor respectievelijk economie of zorg te kiezen met bijna een vijfde af (18\%). Leerlingen die kiezen voor techniek laten zich doorgaans dus minder leiden door afstand. Zij kiezen bijvoorbeeld vaker voor een technische studie vanwege een sterke intrinsieke motivatie (zie ook Cörvers et al., 2005).

De resultaten laten verder zien dat de regionale spreiding van opleidingen er toe kan leiden dat leerlingen voor een alternatieve sector kiezen. Wanneer technieklocaties verder weg gelegen zijn kiezen leerlingen doorgaans vaker voor economie. Tevens blijkt dat wanneer economielocaties verder weg gelegen zijn, leerlingen eerder voor zorg zullen kiezen. Wanneer de afstand tot zorglocaties toeneemt, kiezen leerlingen vaker voor economie en in mindere mate voor techniek. Daarnaast blijkt uit aanvullende analyses dat de afstandgevoeligheid kan verschillen tussen verschillende groepen (i.e. mannelijke autochtonen, mannelijke allochtonen, vrouwelijke autochtonen en vrouwelijke allochtonen).

Voor beleidsmakers kan het van belang zijn rekening te houden met de hier gevonden resultaten. Door de daling van het aantal leerlingen in veel regio's in Nederland zullen meerdere ROC's noodgedwongen een aantal kleinere opleidingslocaties moeten sluiten of samenvoegen met andere locaties. Ook samenwerking tussen ROC's kan daarbij een optie zijn. De concentratie van opleidingen kan consequenties hebben voor de deelname van leerlingen aan de verschillende opleidingssectoren. Bij de strategische keuze betreffende de spreiding van opleidingen over locaties dient zowel rekening te worden gehouden met de keuzes van leerlingen voor bepaalde sectoren onder invloed van de dagelijkse afstand die zij moeten overbruggen van thuis naar school, als het behoud van leerlingen voor de ROC's.

Hoewel de analyses in deze studie zijn uitgevoerd voor slechts één regio en niet alle middelbare beroepsopleidingen in de betreffende regio konden worden betrokken in de analyse, is er een hele goede 'regionale dekking' van de totale populatie van jongeren die voor het mbo kiezen. Een ander voordeel van de 
analyse is dat voornamelijk de pendelbeslissing en in mindere mate de verhuisbeslissing van leerlingen wordt gemodelleerd bij het verklaren van geografische mobiliteit. Het is voor de betreffende groep eerstejaarsleerlingen in het mbo die een paar maanden daarvoor het voortgezet onderwijs hebben verlaten niet zo gebruikelijk om op kamers te gaan wonen. Bijna driekwart van de dataset bestaat uit bol-leerlingen en hiervan is bekend dat het grootste deel nog bij de ouders woont. In veel andere studies spelen echter zowel pendelen als verhuizen een rol bij het verklaren van geografische mobiliteit, waarbij het moeilijk is om beide vormen van mobiliteit te onderscheiden. Men kan immers achteraf in de nabijheid van een opleiding zijn gaan wonen, terwijl de eerdere woonplaats niet uit dataset bekend is. In de dataset die wij gebruiken gaat het bovendien uitsluitend om eerstejaarsleerlingen die in het jaar ervoor geen opleiding volgden op het betreffende ROC. Daardoor wordt de kans verkleind dat de keuze voor een opleiding wordt vertroebeld met eerdere keuzes die gemaakt zijn, zoals het veranderen van opleiding en/of locatie.

Toekomstig onderzoek over de rol van afstand bij de keuze voor een opleiding zou zich kunnen richten op het effect van enkele andere factoren die ook een rol kunnen spelen bij dit keuzeproces. Te denken valt onder andere aan de invloed van het inkomen van de ouders, de nabijheid van openbaarvervoervoorzieningen en de kwaliteit van de aangeboden opleidingen. 


\section{Literatuur}

Baryla, E.A. \& Dotterweich, D. (2001), Student Migration: Do Significant Factors Vary by Region?, Education Reviews, 9 (3), pp. 269-280.

Becker, G.S. (1964), Human Capital; A Theoretical and Empirical Analysis, with Special Reference to Education. General Series; No. 80; New York, NBER.

Becker, G.S. (1975), Human Capital: A Theoretical and Empirical Analysis with Special Relevance to Education, Second edition, New York, NBER.

Bloemen, H. \& Dellaert, B. (2000), De studiekeuze van middelbare leerlingen, Een analyse van motieven, percepties en preferenties, OSA A 176, Tilburg.

Borghans, L. (1999), Arbeidsrelevante studie- en beroepskeuzes van jongeren, OSA A 168, Tilburg.

Borghans, L. \& De Steur, M. (1999), Kiezen voor de zorg. Een conceptueel kader, OSA-Z 39, Tilburg.

Cornielje, J. (2004), Grensoverschrijdend leren in de techniek, De kwaliteit van het Nederlandse technisch beroepsonderwijs aan de hand van de stroom van Nederlandse leerlingen naar Vlaanderen, Faculteit der Cultuurwetenschappen, Universiteit Maastricht.

Cörvers, F., Coenen, J. Heijke, H. \& Montizaan, R. (2005), Het technisch beroepsonderwijs in het Technogebied Zuidoost-Nederland, ROA-R-2005/7, Maastricht.

DesJardins, S.L., Dundar, H. \& Hendel, D.D. (1999), Modeling the College Application Decision Process in a Land-Grant University, Economics of Education Review, 18, pp. 117-132.

Frenette, M. (2006), Too Far to Go On? Distance to School and University Participation, Education Economics, 14 (1), pp 31-58.

Greenwood, M.J. (1975), Research on Internal Migration in the United States: A Survey, Journal of Economic Literature, 13 (2), pp. 397-433.

Hair, J.B., Babin, B., Money, A.H. \& Samouel, P. (2003), Essentials of Business Research Methods, New York: John Wiley \& Sons, Inc.

Huijsman, R., Kloek, T., Kodde, D.A. en Ritzen, J.M.M. (1986), An empirical analysis of college enrollment in the Netherlands, De Economist, 134 (2), pp. 181-190.

Leppel, K. (1993), Logit estimation of a gravity model of the college enrollment decision, Research in Higher Education, 34 (3), pp. 387-398.

Mixon, F.G. \& Hsing, Y. (1994), The Determinants of Out-of-State Enrollments in Higher Education: A Tobit Analysis, Economics of Education Review, 13 (4), pp. 329-335.

Sá, C., R.J.G.M. Florax \& P. Rietveld (2004), Determinants of the Regional Demand for Higher Education in The Netherlands: A Gravity Model Approach, Regional Studies, 38 (4), pp. 375-392. 
Schaafsma, J. (1976), The Consumption and Investment Aspects of the Demand for Education, Journal of Human Resources, 11 (2), pp. 233-242.

Soutar, G.N. \& Turner, J.P. (2002), Students' preferences for university: a conjoint analysis, International Journal of Educational Management, 16, pp. 40-45.

Stouffer, S.A. (1940), American Sociological Review, pp. 846.

Tuckman, H.P. (1970), Determinants of college student migration, Southern Economic Journal, 37, pp. 184-189.

Virtanen, H. \& Väänänen, L. (2010), Supply of Education and Schooling choices, gepresenteerd op XIX Meeting of the Economics of Education Association, juli, Zaragoza.

Vrontis, D., Thrassou, A. \& Melanthiou, Y. (2007), A contemporary higher education student-choice model for developed countries, Journal of Business Research, 60, pp. 979-989. 


\section{Bijlage}

Figuur 1.1

Gemeentes in het onderzoeksgebied waar ten minste één technieklocatie gevestigd is

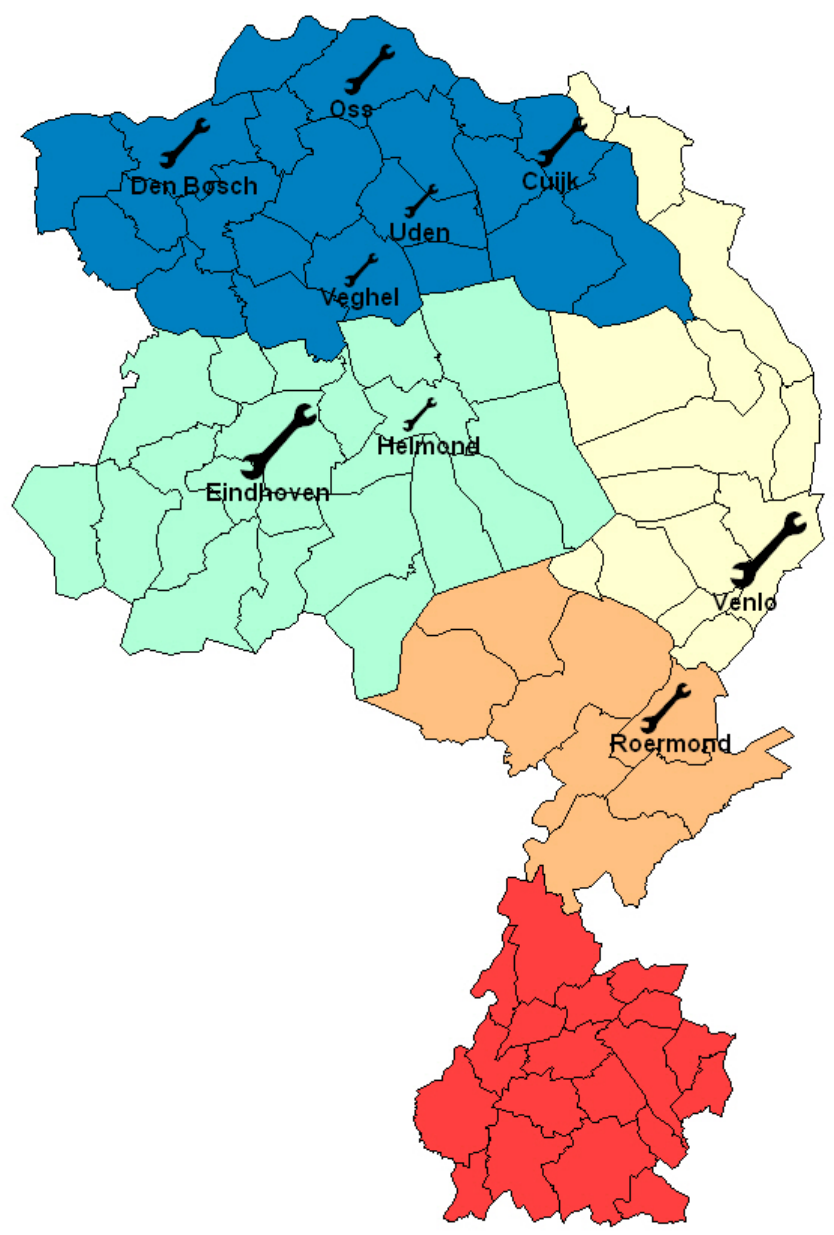

Opmerking: Een groter symbool duidt op meer locaties binnen dezelfde gemeente. 
Figuur 1.2

Gemeentes in het onderzoeksgebied waar ten minste één economielocatie gevestigd is

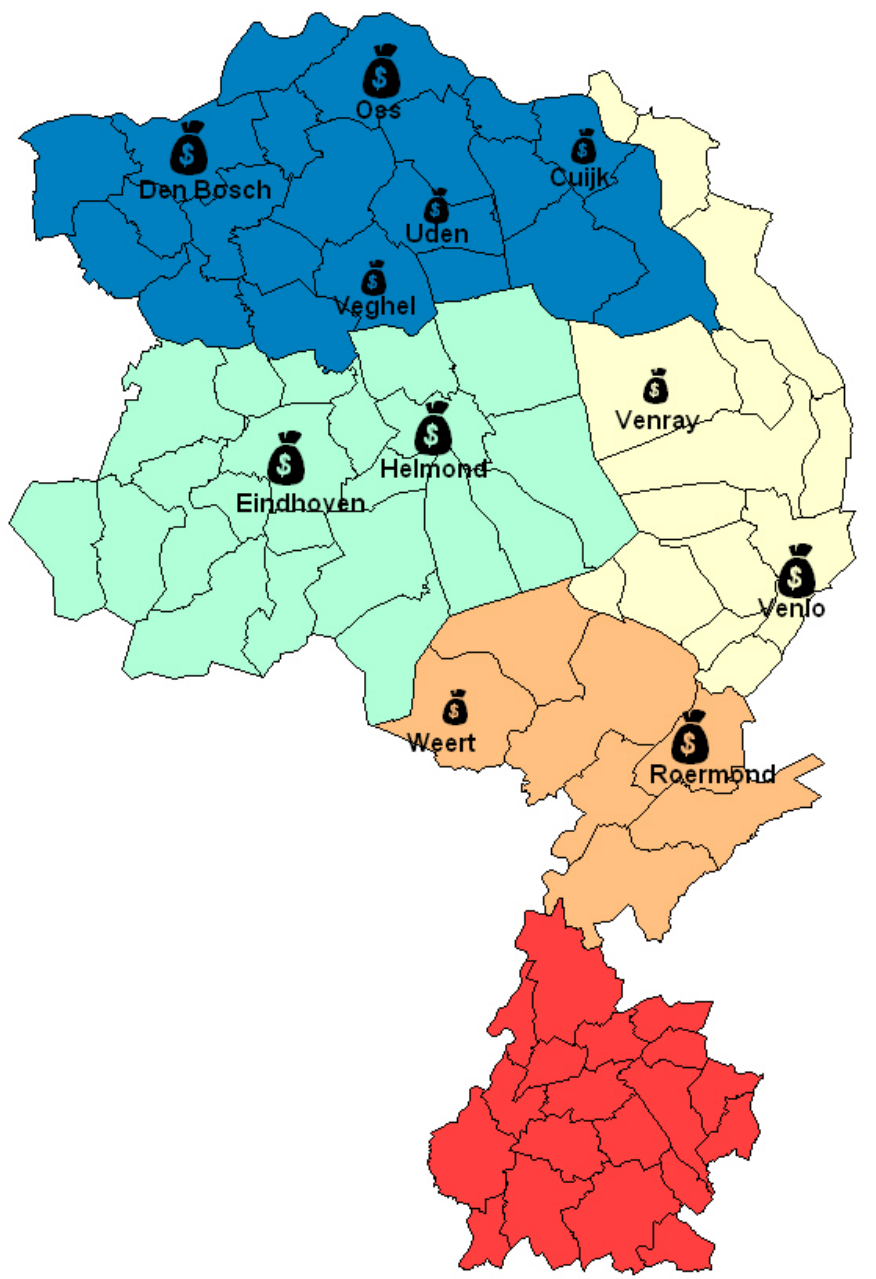

Opmerking: Een groter symbool duidt op meer locaties binnen dezelfde gemeente. 
Figuur 1.3

Gemeentes in het onderzoeksgebied waar ten minste één zorglocatie gevestigd is

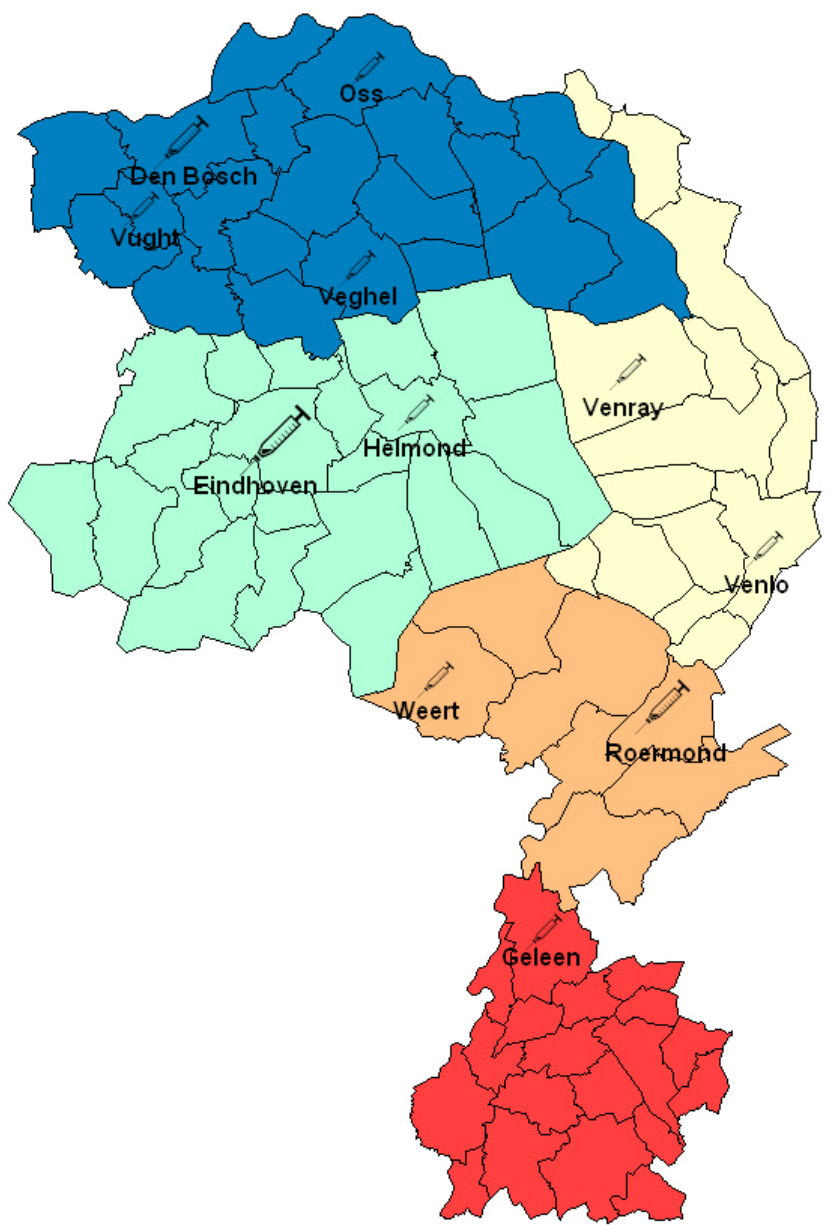

Opmerking: Een groter symbool duidt op meer locaties binnen dezelfde gemeente. 